\title{
فعالية مسرحة المناهج في تنمية التحصيل الدراسي لتلاميذ الصف الثاني الإعدادي المهني في مادة الدراسات الاجتماعية
}

\author{
د. محمد عبدالحليم السيد سرور \\ مدرس المسرح بقسم الإعلام التربوي \\ كلية التربية النوعية - جامعة المنوفية
}

مستخلص البحث:

هدفت الدراسة إلى التعرف على مدى فاعلية توظيف مسرحة المناهج فى مادة الدراسات الاجتماعية على تتمية التحصيل الدراسي لتلاميذ الصف الثاني الإعدادي المهني، واتبع الباحث المنهج التجريبي، وطبقت الدراسة على عينة من تلاميذ الصف الثاني الإعدادي

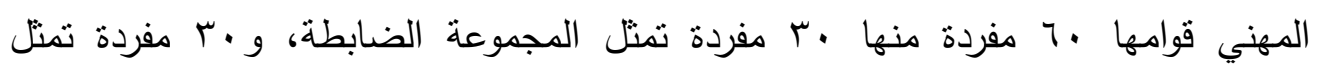

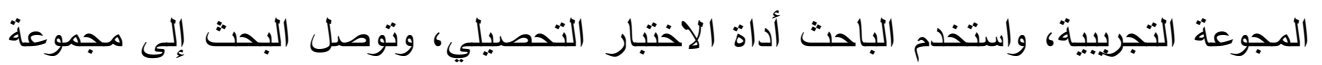
من النتائج أهمها: ا -عدم وجود فروق دالة إحصائيًا بين متوسط درجات المجموعة التجريبية ومتوسط درجات المجموعة الضابطة فى التطبيق القبلى على الاختبار التحصيلى. ץ-عدم وجود فروق دالة إحصائًّا بين متوسط درجات المجموعة الضابطة فى التطبيق القبلى ومتوسط درجات المجموعة الضابطة فى التطبيق البعدى على الاختبار التحصبلى. ب-وجود فروق دالة إحصائيًا بين متوسط درجات المجموعة الضابطة فى التطبيق البعدي ومتوسط درجات المجموعة التجريبية فى التطبيق البعدى على الاختبار التحصيلى لصالح تلاميذ المجموعة التجريبية فى التطبيق البعدى. ع -وجود فروق دالة إحصائيًا بين متوسط درجات المجموعة التجربيية فى التطبيق القبلى ومتوسط درجات المجموعة التجريبية فى التطبيق البعدى على الاختبار التحصيلى لصالح تلاميذ المجموعة التجريبية فى التطبيق البعدى. ه-وجود فروق دالة إحصائيًا بين منوسط درجات المجموعة الضابطة ومتوسط درجات المجموعة التجريبية فى التطبيق البعدى على الاختبار التحصيلى لصالح تلاميذ المجموعة التجريبية فى التطبيق البعدى.

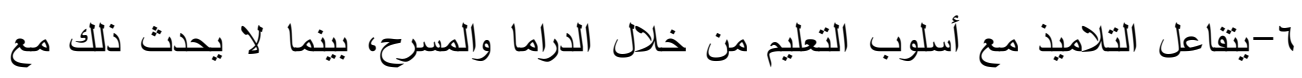
الطرق التقليدية في التدريس التي تعتمد على الإلقاء والمحاضرة. 


\title{
The efficiency of curriculum dramatization In the development of instructional understanding for vocational
}

\author{
second year reparatory in social studies \\ DR : Mohammed Abdel Haleem \\ Elsayed Soroor \\ Professor of theatre in educational \\ information department. Faculty of \\ specific education Menoufia University
}

\section{Research summary:}

This study aims at finding out the effect of applying curriculum dramatization in social studies on the instructional understanding for Vocational second year preparatory.The researcher used the experimental method. This study was applied on a sample of 60 students of Vocational second year. preparatory. 30 students of them represent the regulator group and the other 30 students represent the experimental group. the researcher used the understanding test tool. He found out a group of results. the most important of them are:

1- There are no statistical differences among score averages for the experimental group and the regulator group in the application before the test .

2- There are no statistical differences between score overages for the regulator group in the previous application and in the flowing application in test.

3- There are statistical differences between score average of regulator group in the following application and score average of experimental group is the following application of understanding test for the sake of. The experimental group students in the following application.

4- There are no statistical differences between score overages of experimental group in the previous application and score averages for regulator group in the following application on understanding test for the sake of experimental group students in the following application.

5- There are no statistical differences between score overages of experimental group in the previous application on understanding test for the sake of experimental group.

6- The students react with education method through drama and theatre but that doesn't happen with traditional methods. F teaching which happened on lecture and discussion . 
مقدمة:

يُعد نشاط المسرح داخل المؤسسات التعليمة بمنزلة رئة الأنشطة التربوية جمعاء، ولا غرابة في ذللك؛ فإذا كان المسرح أبا الفنون -كما يقولون- فإن النشاط المسرحي أبو النيو الأنشطة التربوية بالمدرسة، ذلك أن العرض المسرحي يتضمن جميع الفنون الأخرى من فنون

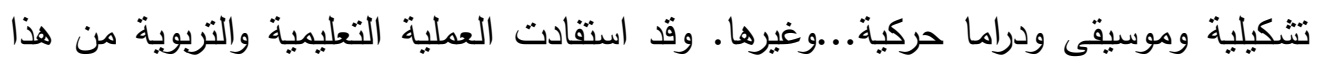

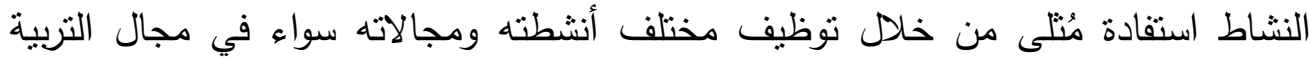

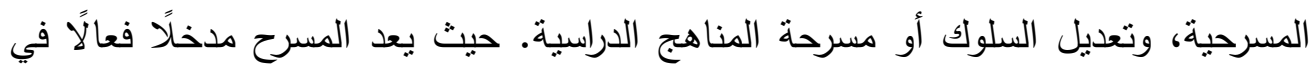

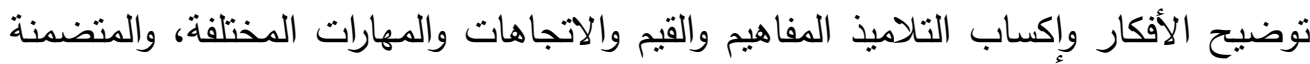

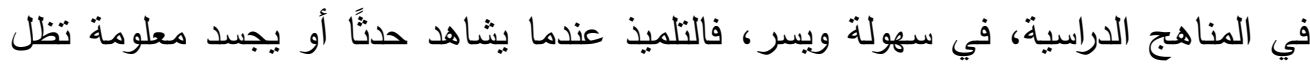

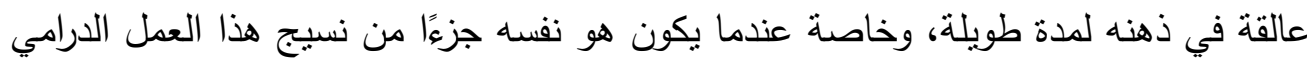

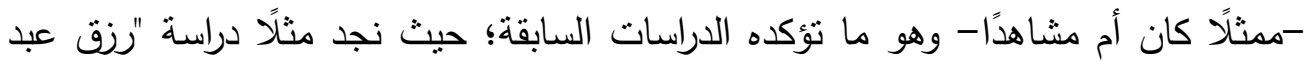

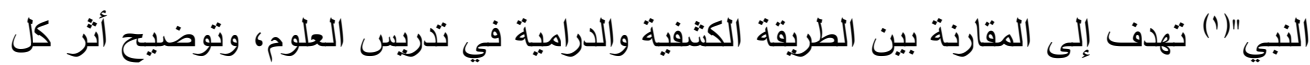
منهما على التحصيل والتفكير والاتجاه العملي لدى الطلاب؛ حيث توصلت إلى أن الطريقة

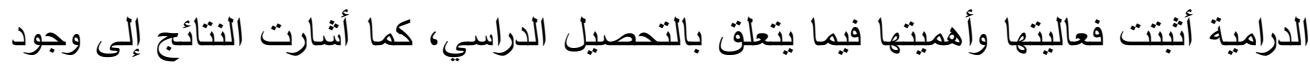
فروق ذات دلالة إحصائية بين متوسط درجات المجموعة التجريبية والمجموعة الضابطة في الاختبار التحصيلي البعدي لصالح المجموعة التجريبية.

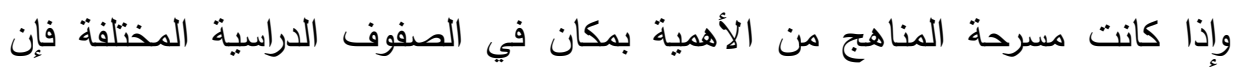

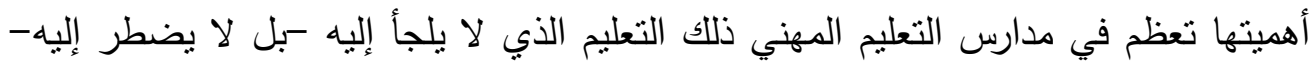

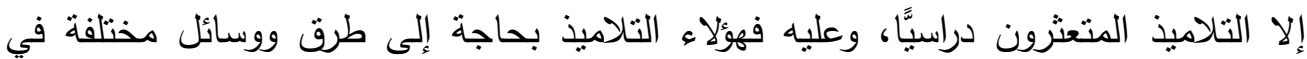
التدريس تكون جذابة ومحببة لديهم بعيدًا عن التلقين الحفظ والاستظهار . وتم في هذا دراسة درجة تحصيل تلاميذ الصف الثاني الإعدادي المهني لمادة الدراسات الاجتماعية والتزكيز على وحدة تعليمية بعنوان "النقل والتجارة"، وجاء اختبار هذه الوحدة

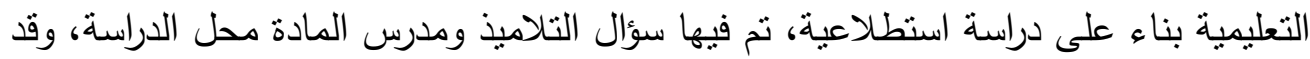
اتفقوا على صعوبة هذه الوحدة وتداخل معلوماتها لدى التلاميذ مما يؤدي إلى ضعف داه استيعابهم وسرعة نسيانهم لها. ويهتم البحث الحالي بتوجيه نظر القائمين على تعليم هذه الفئة من التلاميذ إلى أهمية

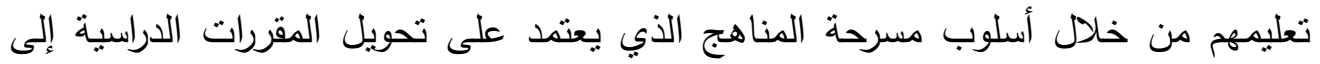

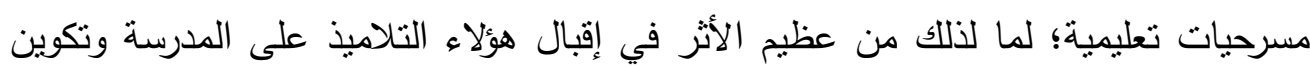

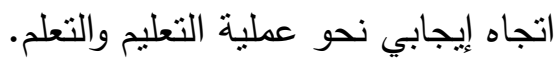


مع التأكيد على أن توظيف أسلوب مسرحة المناهج في العطلية التعليمة داخل المدرسة

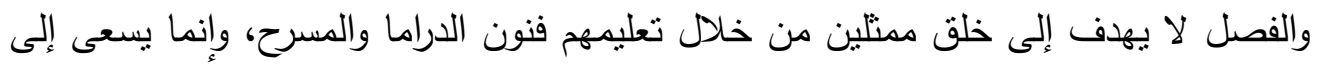
تعليم هؤلاء التلاميذ المقررات الدراسية من خلال الدراما والمسرح، وهذا يؤكد دومًا أن النشاط فئاط المسرحي داخل المدرسة وسيلة وليس غاية.

وحتى ينجح المعلم في تحقيق الأهداف المرجوة من وراء استخدام أسلوب التعليم بالدراما

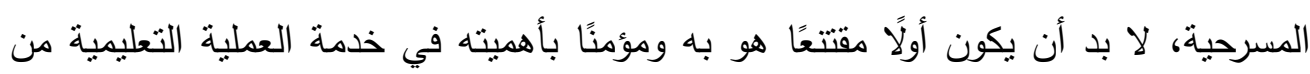

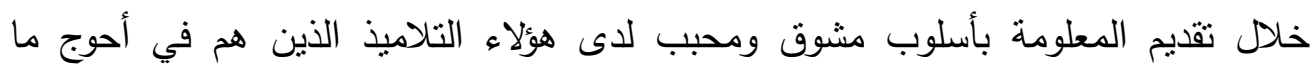

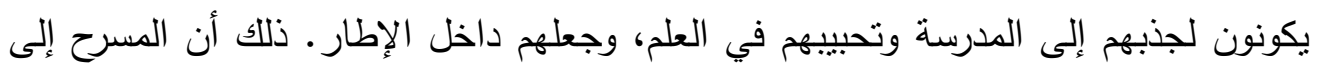

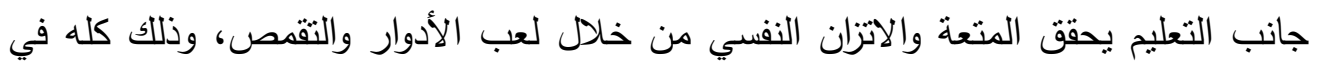

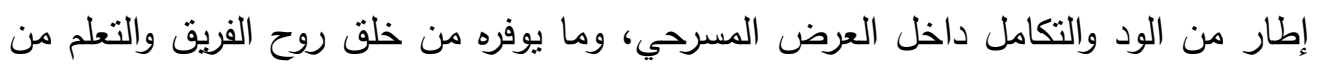
خلا الخبرة وممارسة المعلومة بدلًا من التلقين.

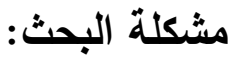

لا حظ الباحث من خلال متابعتة لمجموعات التربية الميدانية في المدارس؛ عدم تفعيل

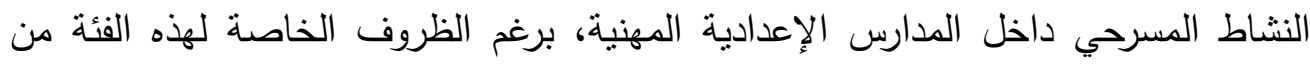
التلاميذ التي تعثرت في التعليم العادي -المعتمد على الحفظ والتلقين - فالتحقت بالتعليم

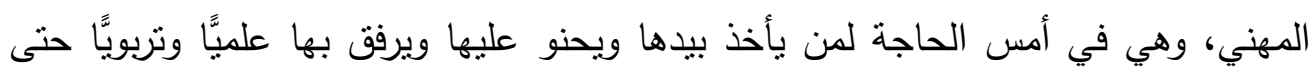

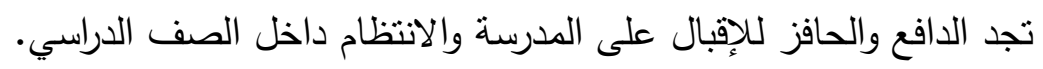

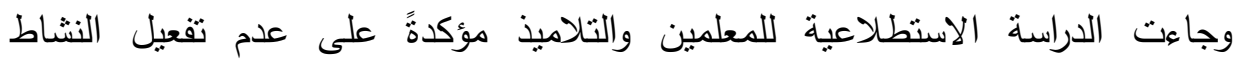
المسرحي واعتماد المعلمين على الطرق التقليدية في التدريس، وذلك نتيجة لعدم إدراك معظم

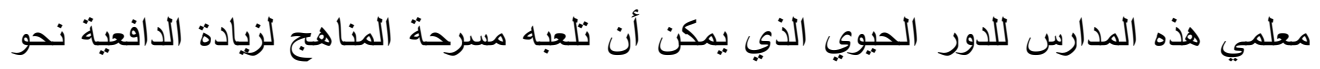

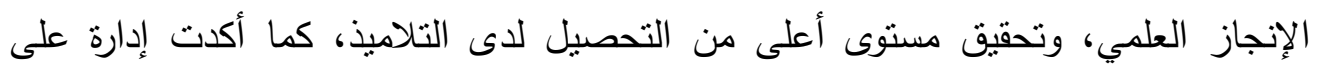

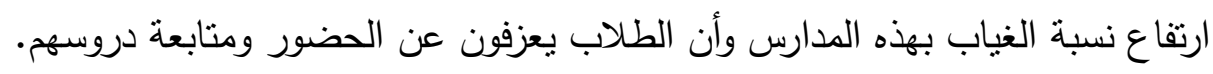
وما يؤكد المشكلة البحثية أيضًا ما دلت عليه نتائج الدراسات السابقة -الأجنبية

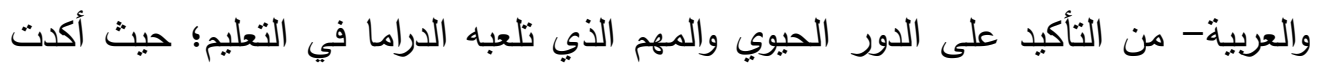

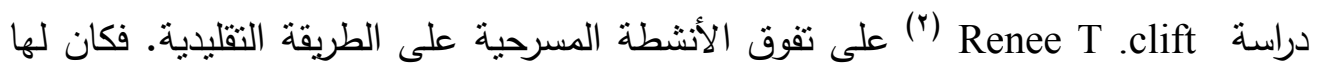
آثار إيجابية على حماس الطلاب أثثاء التعلم. وأن الأنشطة المسرحية تسهم في الثية حل الكثير

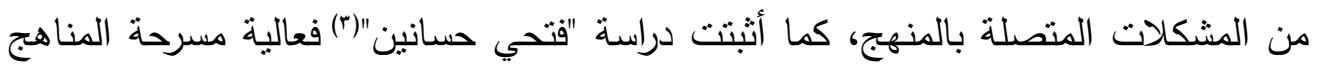


في فهم قواعد النحو وزيادة التحصيل لدى تلاميذ المرحلة الابتدائية. وجاءت جميع الدراسات

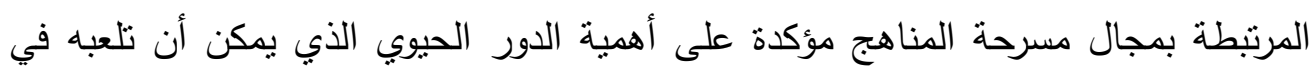

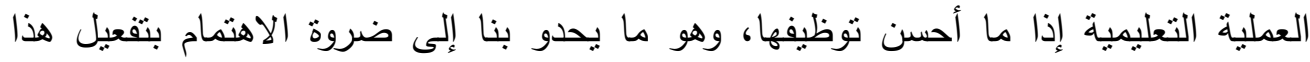
الدور داخل مدارس المرحلة الإعدادية المهنية لتحقيق الاستفادة القصوى. ويناء على ما سبق تتلخص مشكلة البحث في التساؤل الرئيسي التالي:

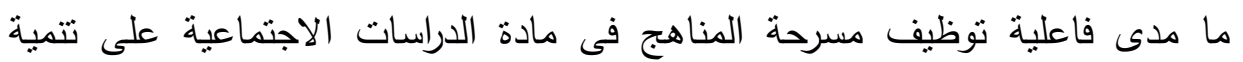

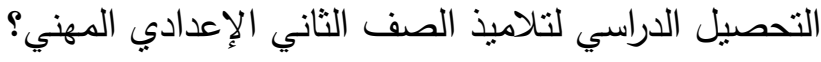
أهداف البحث: - (أبث:

\section{يرهف البحث الحالي إلى ما يلي:}

ا ـ التعرف على فاعلية توظيف مسرحة المناهج فى مادة الدراسات الاجتماعية على تتمية

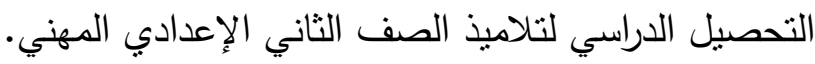

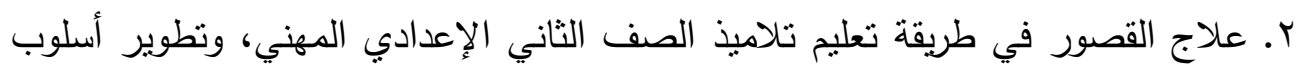
تعليمهم من خلال الاعتماد على إمكانيات الدراما في التعليم بمسرحة المناهج الدراسية.

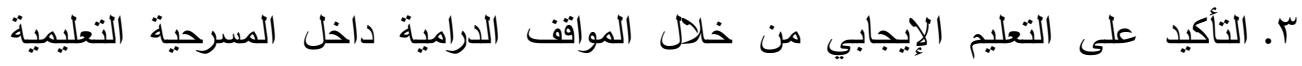
واكتساب المعلومات من خلال الخبرة سواء للتلميذ الممارس أو المشاهد بعيدًا عن التلقين التقلبدي.

$$
\text { أهمية البحث: }
$$

ا ـ توجيه أنظار المعلمين في المدارس الإعدادية المهنية للدور الذي يمكن أن يلعبه تحويل المقررات الدراسية إلى مسرحيات تعليمية في تتمية التحصيل الدراسي وزيادة دافعية هؤلاء التلاميذ نحو الإنجاز العلمي. r. دعم المناهج الدراسية والتأكيد على التعلم من خلال المواقف الدرامية واكتساب التلاميذ للمعلومات من خلال الممارسة ولعب الأدوار بعيدًا عن أسلوب التلقين التقليدي.

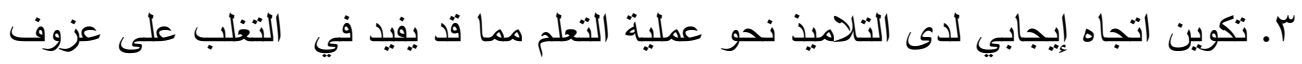
الكثير من طلاب هذه المدارس عن حضور دروسهم داخل الصف الدراسي التقليدي.

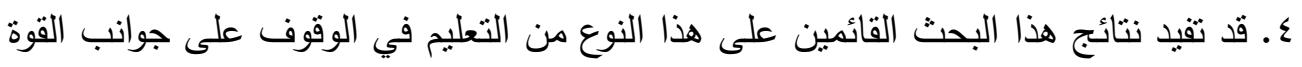

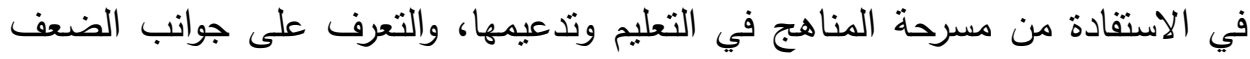

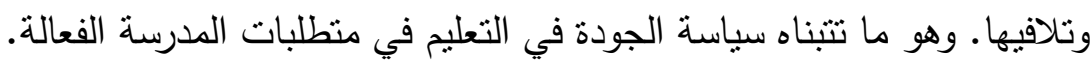




\section{نوع ومنهج البحث:}

ينتمي البحث إلى الدراسات التجريبية "التي ترصد دخول متغير مسنقل في ظل الظروف الطبيعية مع التحكم إلى حد ما في بعض المتغيرات الوسيطة، وذلك بهدف قياس فاعلية

المتغير المستقل على المتغير التجريبي"(أ). ويعتمد هذا البحث على المنهج التجريبي الذي يستهدف قياس تأثير دخول متغير مسرحة المناهج على عينة من تلاميذ الصف الثاني الإعدادي المهني في جوانب التحصيل الدراسي مستخدمًا في ذلك أسلوب المجموعتين إحداهما ضابطة والأخرى تجربيية.

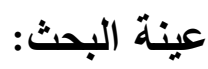

تم اختيار عينة عشوائية من تلاميذ الصف الثاني الإعدادي المهني بمدرسة فاطمة

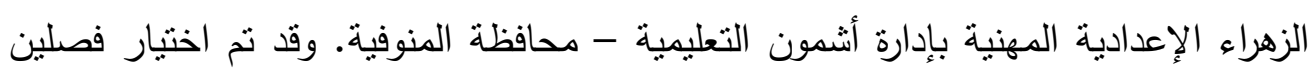

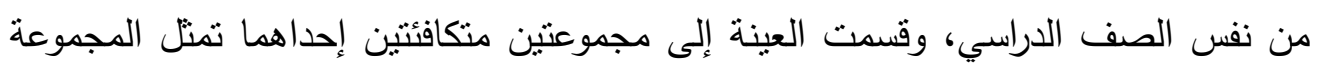
التجريبية وتتكون من · r مفردة، والأخرى هي المجموعة الضابطة، وتتكون من • ب مفردة.

$$
\text { أدوات البحث: }
$$

يستخدم البحث الحالي أداة الاختبار التحصيلي ويتم تطبيقه على التلاميذ عينة البحث

من أفراد المجموعتين الضابطة والتجريبية.

$$
\text { تقدم حدود البحث: }
$$

1- حدود بشرية: تضم عينة من تلاميذ الصف الثاني الإعدادي المهني بمدرسة فاطمة

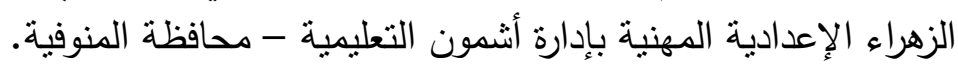

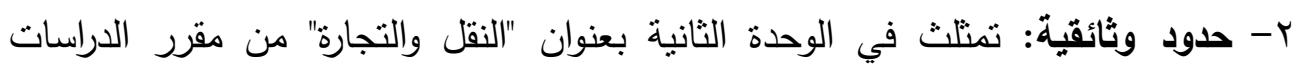

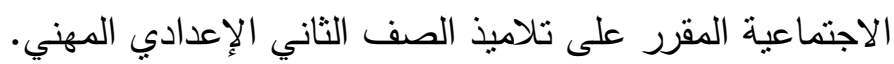

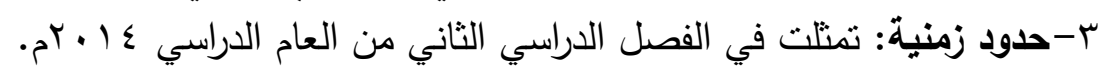

الاور التعليمي للمسرح داخل المدرسة: تشكل مسرحة المناهج أو توظيف المسرح في العملية التعليمية مجالًا مهمًّا من مجالات المسرح داخل المؤسسات التعليمية؛ حيث إن هذه المسرحيات التعليمية المرتبطة بالمناهج الدراسية، تستخدم كوسيلة تعليمية تهدف إلى تبسيط وتفسير بعض جوانب المقررات الدراسية

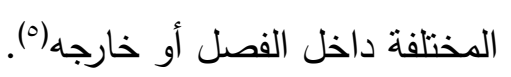


ولعل ما يميزها هو إيجابيتها بالنسبة للتلاميذ المشاركين فيها، فهي تعمل على أن يندمج

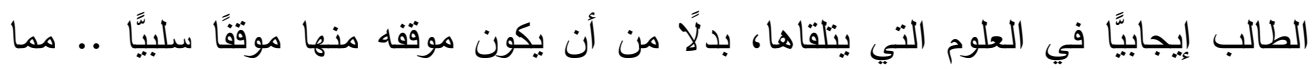
يساعد الطلاب على تيسير الفهم وتعميق الأثر ، وسهولة التذكر في قالب محبب لديهم يمتزج فيه التحصيل بالمتعة (؟). وينطلق هذا البحث من تحديد مفهوم مسرحة المناهج كمصطلح فقد تعددت تعريفات مسرحة المناهج، فهناك من ينظر إليها باعتبارها طريقة من طرق التدريس، وهناك من يعتبرها

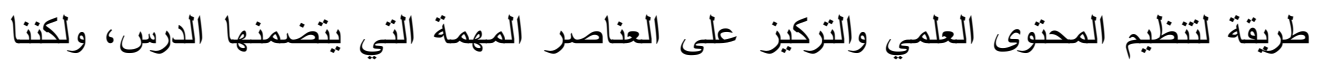
في الواقع نجد أن مسرحة المناهج ليست طريقة من طرق التدريس، بل هي وسيلة تعليمية، ذلك أن طرق التدريس متاحة لكل معلم يمكنه توظيفها داخل الصف بئن بئما مسرحة المناهج

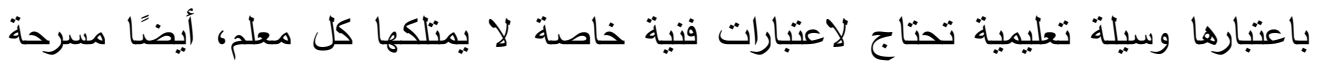

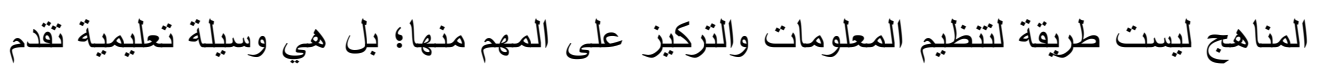

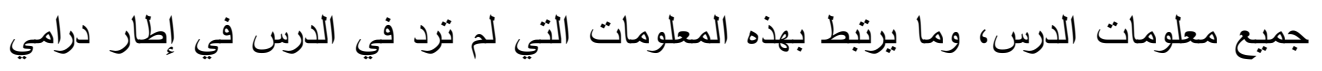
مرتبط بخبرة حياتية بهدف تعليم التلاميذ. وعليه يتبنى الباحث التعريف التالي لمسرحة المناهج باعتبارها: "إعادة تقديم الموضوع

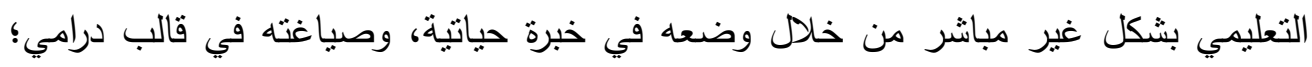

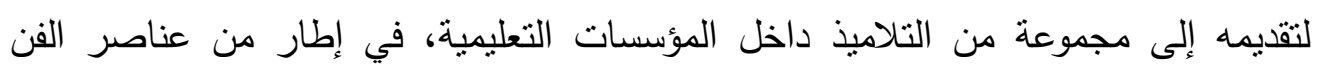
المسرحي بهدف تحقيق مزيد من الفهر والتفسير"(V). أهداف التعليم باستخدام الدراما:

للاراما دور نربوي من خلال المنهج الدراسي، والواقع أن معالجة محتوى المنهج وتقديمه

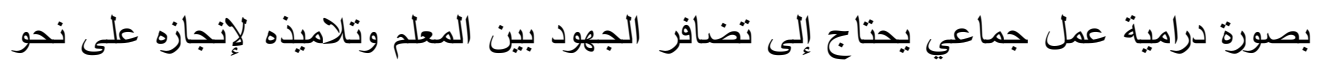

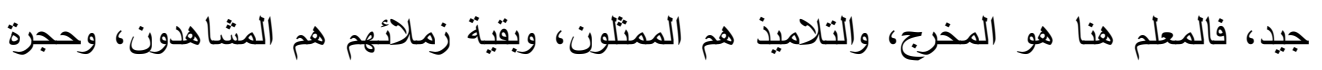
الدرس غالبًا ما تكون هي المسرح، والنص هنا يعتمد على محتوى المنهج الدراسي (^). ونجد أن أهداف التعليم بالدراما متتوعة وكثثرة نذكر منها: 1-معاونة التلميذ على استخدام الثكل الدرامي في نشاطه. r-تشجيع التلميذ على التفكير وتحسين خبراته من خلال الدراما.

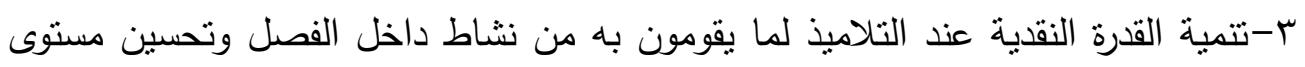
تمتعهم به وبالنشاط الدرامي كلما اتسع مفهومهم له.

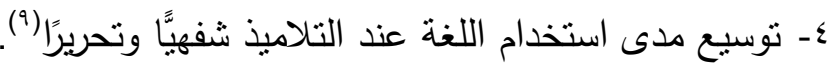


كذلك نجد أن التعليم باستخدام الدراما يتيح نوعًا من التعلم هو (التعلم بالملاحظة) ونقصد به ملاحظة التلاميذ لثخوص المسرحية وبصفة خاصة الثخصيات التي تلعب أدوارًا

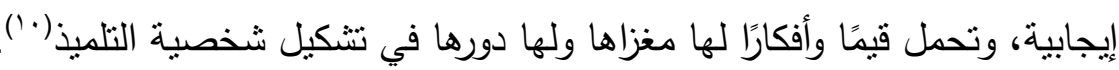
وقد كثفت دراسة إيمان خضر (')'، عن الدور الحقيقي الذي يمكن أن تلعبه مسرحة المناهج في العملية التعليمية داخل المدرسة، وكذلك توظيف تكنيك الديك الدراما لخدمة العملية التعليمية، وذلك باستخدام مسرحة المناهج كأحد طرق التدريس داخل الفصل الدراسي. وقد

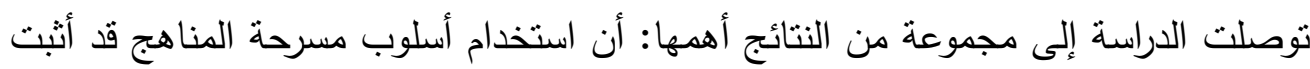
بالدليل الإحصائي فعاليته في تحصيل تلاميذ المجموعة التجريبية. ووصلت نسبة تفاعل

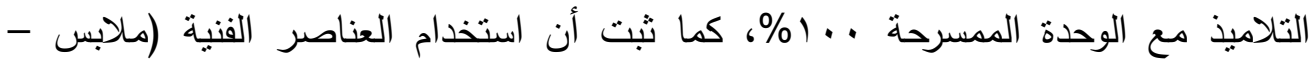
إكسسوار - موسيقى) كمكملات للعرض الفني بنسبة سم٪\%، ويمكن تتفيذ الوحدة المدسرحة بدونه إذا تعذر ذلك. كما أن التغيير في شكل الفصل الدراسي جذب انتباه التلاميذ بنسبة .\%1..

وهو ما يؤكد على أهمية الدور الحيوي الذي تقوم به مسرحة المناهج في تحقيق أعلى التى معدل لتحصيل التتلاميذ لدروسهم وتحقيق أهداف العملية التعلمبة. أ- أتحصيل الدراسي: - التصني يقصر البعض مفهوم التحصيل الدراسي على المعلومات التي يتحصل عليها التلميذ من المدرسة؛ بينما نجد آخرين لا يقصرونه على تحصيل المعلومات، وإنما يمتد ليشمل إلى جانب لئب لئل

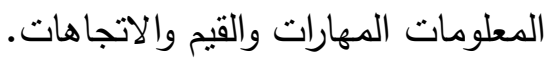
فيعرفه "عبدالسلام أحمد" بأنه: "مدى تحصيل التلاميذ لما تهدف إلبه المدرسة أو

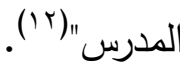
ويرى أبو العزم عبد المنعم" أنه: "مقدار ما يحصله الطالب من خبرات ومهارات في مادة

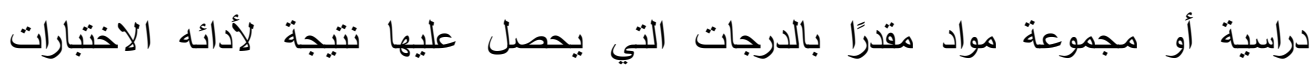

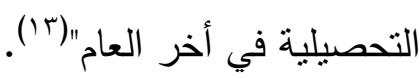
بينما بعرفه "فؤاد أبو حطب" بأنه: " اكتساب المعلومات والمهارات وطرق التقكير وتغير

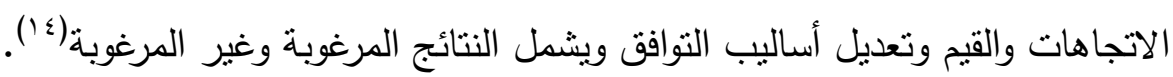

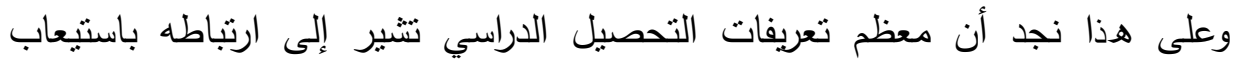
التلاميذ للمواد الدراسية التي يدرسونها وما برتبط بذلك من مهارات وقيم من خلال درجات الأختبارات النهائية للتناميذ. وفي إطار هذا البحث يعرف الباحث التحصيل الدراسي بأنه: 
مقدار ما يحصله تلاميذ الصف الثاني الإعدادي المهني من معلومات وخبرات ومهارات في

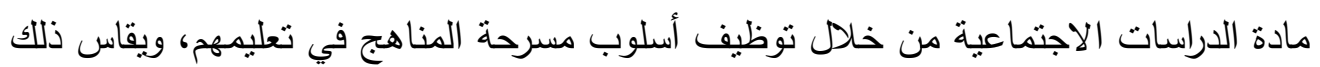
بالدرجات التي يحصلون عليها في الاختبار التحصيلي النهائي عقب العرض المسرحي.

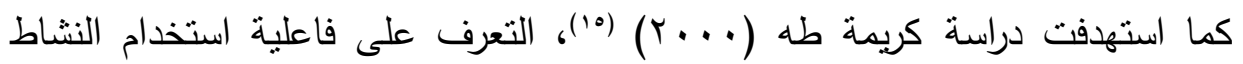
التمثيلي في تدريس وحدة في مادة التاريخ لتلاميذ الصف الأول الإعدادي في تتمية مهارة

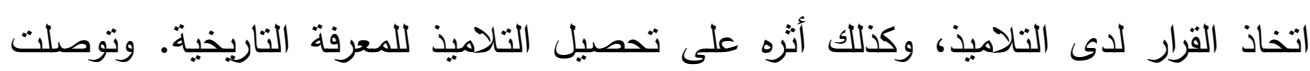
الدراسة إلى مجموعة من النتائج أهمها: وجود فروق ذات دلالة إحصائية بين متوسطات درجات تلاميذ المجموعة التجريبية، ومنوسط درجات تلاميذ المجموعة الضابطة في الاختبار البعدي لصالح المجموعة التجريبية. وكذللك وجود علاقة بين متوسطات درجات تحصيل تلديل تلاميذ المجموعة التجريبية ومستوى إكتسابهم لمهارة اتخاذ القرار في التطبيق البعدي.

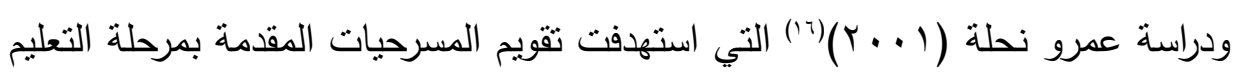

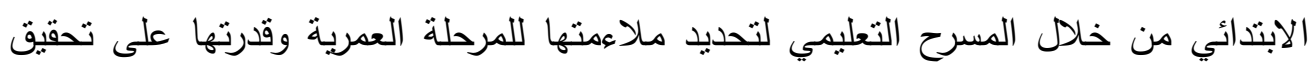
أهداف التربية المسرحية، واستهدفت أيضًا تحليل مضمون المسرحيات المقدمة في المسرح التعليمي (مسرحة المناهج) للتعرف على مدى استطاعة القائم بالإعداد أن يقدم المادة الدراسية في قالب درامي متكامل البناء، واستخدم الباحث المنهج الوصفي التحليلي، واعتمدت الدراسة

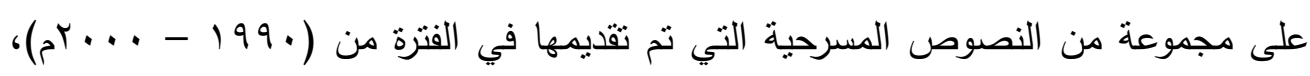

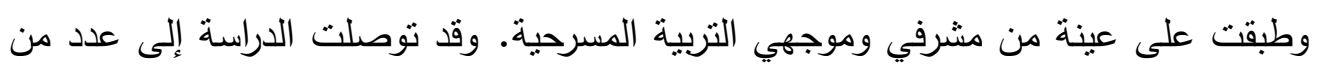

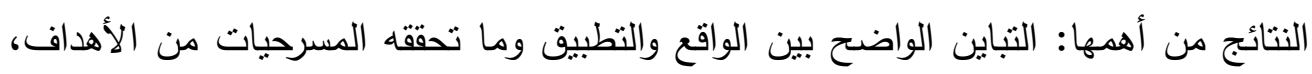

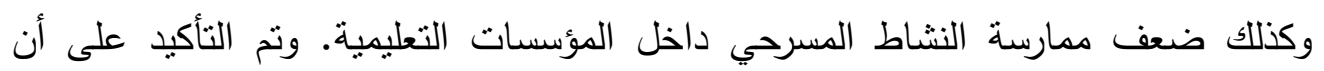
النشاط المسرحي يساعد على تبسيط وتسهيل المعلومات والمعارف التي قد تكون معقدة ونقلها إلى التلاميذ بأسلوب فني مشوق، بينما تتوعت المشكلات التي تعوق تتفيذ النشاط المسرحي بين عدم وجود وقت مخصص لممارسة النشاط المسرحي، وندرة نصوص مسرحة المناهج الخاصة بالمقررات الدراسية، وعدم وعي المسئولين وأولياء الأمور بأهمية المسرح التعليمي. ومن خلال تعرضنا لبعض من أهداف ونتائج الدراسات السابقة المرتبطة بمجال البحث

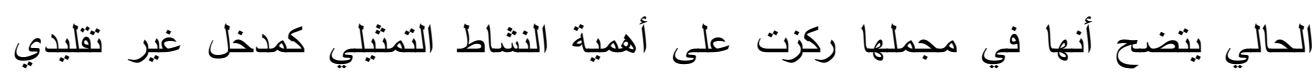
للتنريس، والدور الذي يمكن أن تلعبه مسرحة المناهج داخل مدارسنا في تتمية تحصيل ركيل 
التلاميذ وإكسابهم بعض القيم والمهارات الاجتماعية. واهتمت الدراسات الأجنبية اهتمامًا كبيرًا باستخدام الدراما داخل حجرة الدراسة؛ لما له من آثار إيجابية على حماس التلاميذ أثناء التعلم، كما أن الأنشطة المسرحية تسهم في حل الكثير من المشكلات، وكذلك محاولة الربط

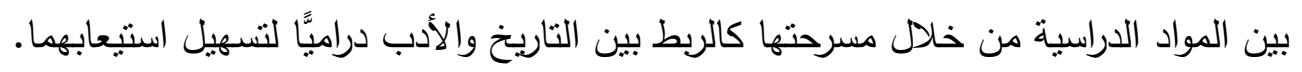
ويتفق البحث الحالي مع الدراسات السابقة في استخدامه مسرحة المناهج كوسيلة غير تقليدية في العملية التعليمية. وتقديم العروض داخل حجرة الدراسة لتحويلها من الإطار التقليدي المألوف إلى مكان أكثر إثارة وتتويق للتلاميذ، بينما يختلف البحث الحالي عن تلائ

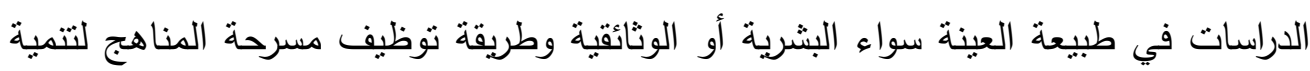
التحصيل الدراسي لدى التلاميذ عينة الدراسة. إجراءات البحث: أولًا: الاختبار التحصيلي: أبلت:

قام الباحث ببناء الاختبار التحصيلي على ضوء المحتوى العلمي للوحدة الدراسية عينة البحث والأهداف السلوكية المنوقعة من التلاميذ، واعتمد الباحث في صياغة أسئلة الاختبار على ثلاثة أنواع من الأسئلة الموضوعية هي: أسئلة الصواب والخطأ، والاختيار من متعددة، وملئ الفراغ. وفيما يلي الخطوات التي مر بها الاختبار : الاسله 1-تحديد الهذف من الاختبار:

يهدف الاختبار إلى قياس تحصيل تلاميذ الصف الثاني الإعدادي المهني للمعلومات والخبرات والمهارات المرتبطة بوحدة "النقل والتجارة" من خلال تحليل نتائج نطبيق الاختبار القبلي والبعدي على المجموعتنين التجريبية والضابطة، ومعرفة مقدار متوسط الفروق بينهما.

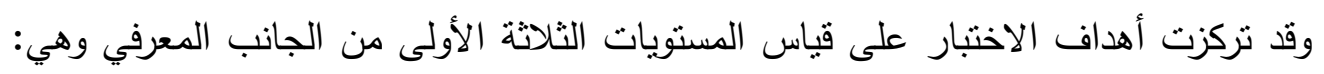

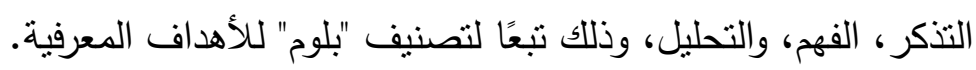

\section{r-بناء الاختبار التحصلي:}

ركز الباحث في بنائه للاختبار أن يكون موضوعيًّا، وذلك لما تحققه الأسئلة الموضوعية

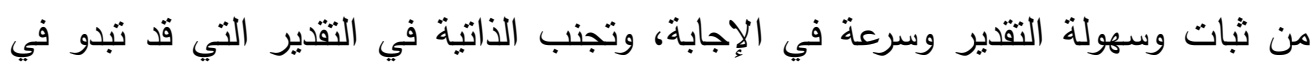

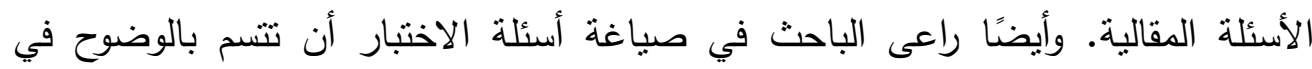

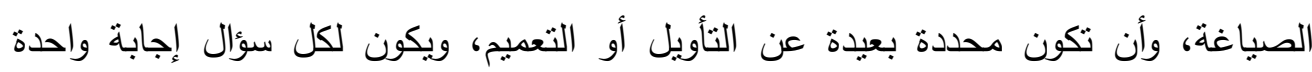


صحيحة، وتبدو جميع البدائل جذابة وفي إطار الموضوع بحيث تبدو كأنها صحيحة. وتم صياغة بطاقة تعليمات للاختبار وتعريف التلاميذ بأهميته ومكوناته وطريقة الإجابة عليه. وقد تتوعت أسئلة الاختبار بين أسئلة الاختيار من متعدد، والصواب والخطأ، وأسئلة مله

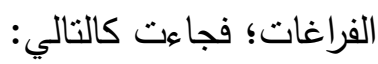

البعد الأول: أسئلة الصواب ( / / ) والخطأ ( x ) وتضم عشرة أسئلة.

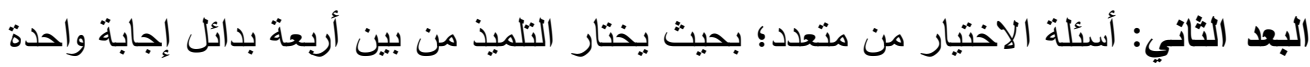
تكون هي الصحيحة، ويضم هذا البعد عشرة أسئلة. البعد الثالث: أسئلة ملء الفراغات، وهذا النوع من الأسئلة يحتاج إلى كلمة أوعبارة حتى تستتم

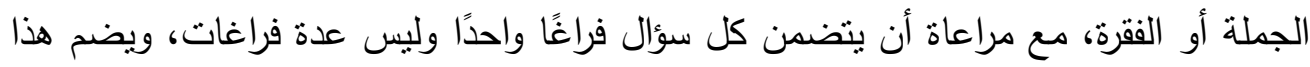
البعد عشرة أسئلة.

\section{r-وضع جدول مواصفات للاختبار:}

يهدف جدول المواصفات للتأكد من أن الاختبار يقيس أهداف المسرحية المنهجية من

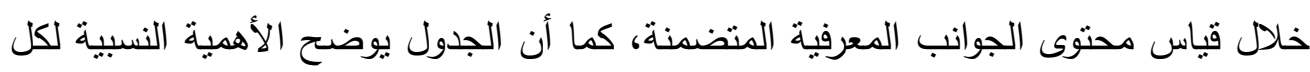

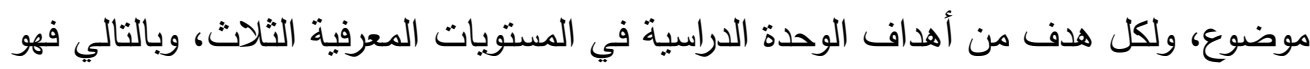
يحدد عدد عبارات الاختبار التي تخصص لكل هدف من أهداف هذه الدروس. وختامًا فقد اهتم الباحث بمراجعة الاختبار مراجعة علمية منهجية ومراجعة لغوية، وعرضه الاحنه على مدرس الدراسات الاجتماعية في المدرسة للتأكد من صحته وملائمته للتناميذ عينة البحث. ثانيًا: التجرية الأساسية (مسرحة الوحدة التعليمية): قام الباحث بمجموعة من الخطوات قبل وأثناء الإعداد الدرامي للوحدة المنهجية، وكذلك الكاديه لتنفيذها داخل حجرة الدرس في صورة عرض مسرحي، وهذه المراحل كالتالي. أ- مرحلة ما قبل مسرحة الوحدة التعليمية: اختار الباحث هذه الوحدة الدراسية -النقل والتجارة- لتقديمها من خلال أسلوب مسرحة مله المناهج داخل حجرة الفصل لعدة أمور منها: 1-اعتراف معلمي العلوم بأن هذه الوحدة تحتاج لمجهود كبير لتوصيل المعلومة للتلاميذ

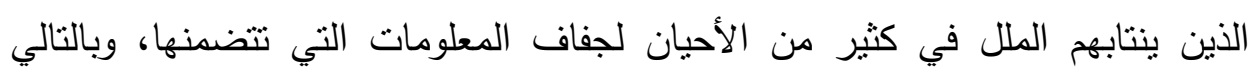
عزوفهم عن حضور دروسهم. 
ץ-من خلال أخذ رأي التلاميذ في مادة الدراسات الاجتماعية ومدى استيعابهم لها أثنار معظم التلاميذ إلى صعوبة وحدة النقل والتجارة؛ حيث تتداخل معلوماتها وتعتمد على لثى الحفظ ومن ثم فهي سريعة النسيان. r-أظهر بعض أولياء الأمور أن أولادهم لا يُقبلون على مثنابعة دروسهم داخل المدرسة

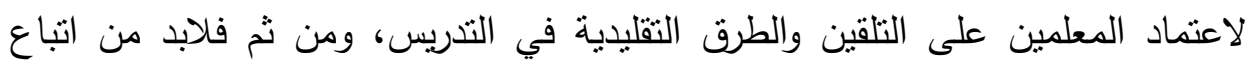
أساليب حديثة في تعليم أبنائهم داخل المدارس الإعدادية المهنية، حيث توفر لهم هذه الأساليب الإثارة والمتعة في تلقي المعلومة فيكون التلميذ شريك في تداول المعلومات بدلاًاً من كونه منلق لها فحسب. ولهذه الأسباب تنبي الباحث هذه المادة الدراسية وقام بالاطلاع وجمع المعلومات حول وحدة "النقل والتجارة" حيث إن الثراء في المعلومات والمعرفة حول الفكرة، يسمح للمُعد بحرية

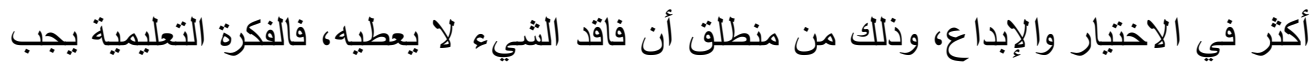

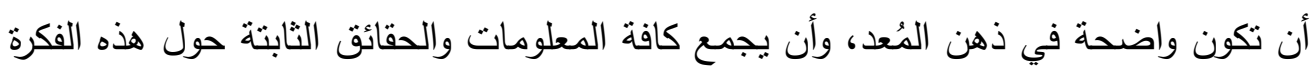
لكي تتحقق المصداقية، وذلك قبل أن يشرع في الكتابة المسرحية. ب- مرحلة كتابة النص المسرحي: قام الباحث باختيار وحدة دراسية بعنوان (النقل والتجارة) من مادة الدراسات الاجتماعية المقررة على تلاميذ الصف الثاني الإعدادي المهني في الفصل الدراسي الثاني، وتم تحديد الأهداف الرئيسية لدروس الوحدة وفي إطار هذه الأهداف تم مسرحة الوحدة وإعادة صياغتها

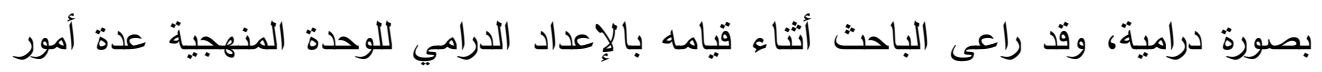

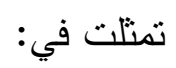
1-تحديد الفكرة التي يمكن من خلالها تقديم الأحداث المسرحية داخل النص تمهيدًا لتجسيدها داخل الفصل في صورة عرض ينبض بالحياة، وراعى الباحث فيها البساطة وجعلها غير مركبة ومناسبة للتلاميذ عينة البحث؛ فجاءت الفكرة واضحة لا لبس فيها ولا باهي غموض يعتريها، انطلافًا من أن العرض المسرحي بدون فكرة جيدة مجرد كلمات وحركات

$$
\text { بلا روح أو معنى. }
$$

r-الالتزام بفنيات الكتابة المسرحية بما يلائم طبيعة مسرحة المناهج. r-جعل النص المسرحي شاملًا جميع أهداف دروس الوحدة ولا يغفل أي منها. 
ع - راعى الباحث إضافة بعض المعلومات غير الواردة في الوحدة، ولكنها في صلب

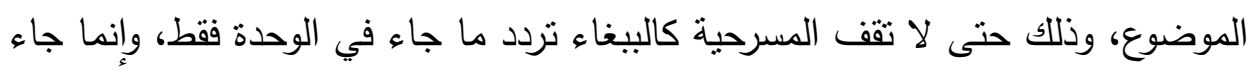
النص يثري الموضوع التعليمي. ه- التركيز على أن يكون أسلوب الحوار سهلًا ولغته فصحى بسيطة بما بتتاسب وطبيعة هذه الفئة من التلاميذ المتعسرين دراسيًا. צ- حاول الباحث في إعداده للنص المسرحي أن يعتمد على عدد قليل من الثخصيات وذلك دريا.

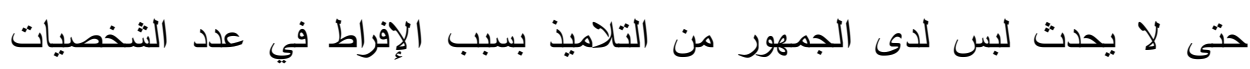
وتداخل الحركة، وبالتالي لا يتحقق الهدف المنشود من مسرحة المناهج، وهو (تحقيق مزيد من التفسير والفهم والاستيعاب لدى التلاميذ).

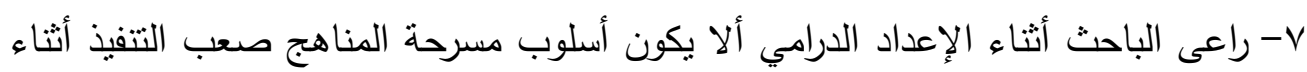

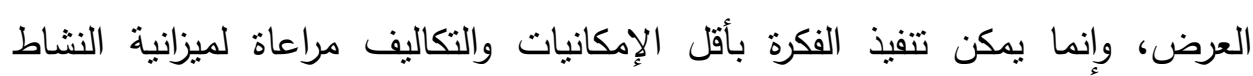

$$
\text { المسرحي المحدودة. }
$$

^- اشتمل النص على ثلاثة مشاهد يتتاول المشهد الأول طرق النقل والمواصلات، بينما يشتمل المشهد الثاني التبادل التجاري بين مصر والدول العربية، ويأني المشهد الثالث والأخير ليوضح التكامل الاقتصادي بين أقطار الوطن العربي.

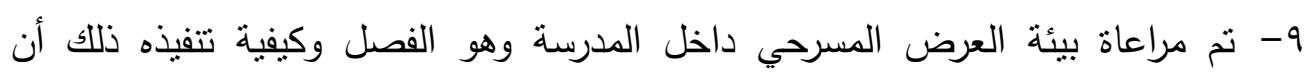
نصوص مسرحة المناهج تكتب لتعرض لا لتقرأ.

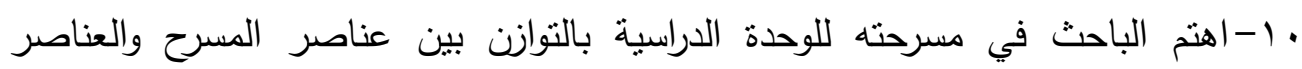

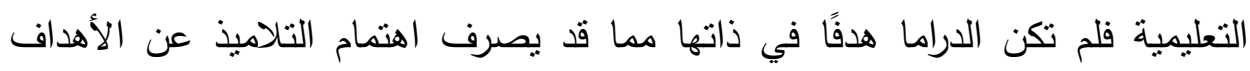

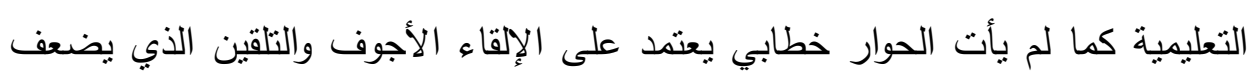

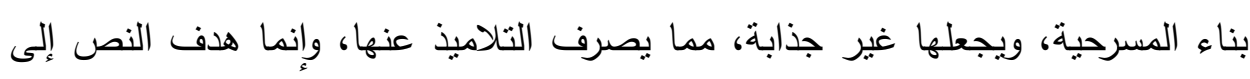
تحقيق التعليم والمتعة المسرحية في آن. وبعد أن فرغ الباحث من مسرحة الوحدة الدراسية قام بمراجعتها وتتضيدها ووضع لهئ لهان

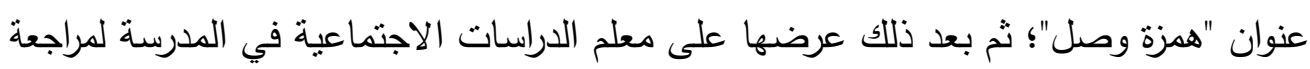
المعلومات الواردة فيها والتأكد من صحتها وأنها وافية وملائمة لتلاميذ هذه المرحلة الدراسية.

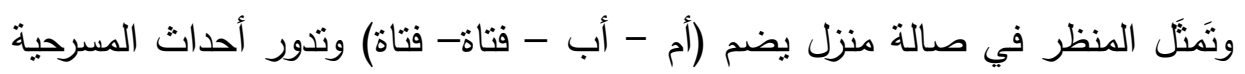
حول فتاة تخرجت في إحدى كليات التجارة وفور حصولها على شهادة التخرج قررت أن تعمل 
في المجال الذي درست فيه وهو التجارة وبالتحديد مجال الاستيراد والتصدير، ودار نقاش حول أفراد الأسرة عن طبيعة هذا المجال من الأعمال وما قد تواجهه من صعوبة في وسائل النقل والمواصلات ويتم الكثف عن أنواع النقل وتتوعه بين بري وبحري وجوي.

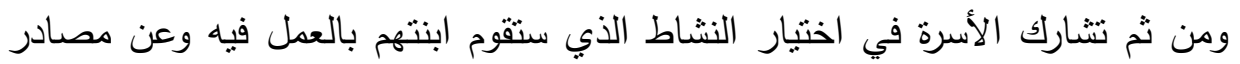

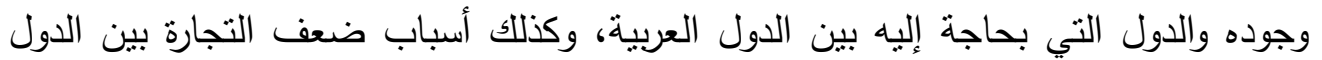
العربية، ويرجع الأب سبب ضعف التجارة العربية إلى الاستعمار الذي قسم الدول العربية، وأقام بينها الحواجز والجمارك ليفرض الأجنبي سطوته على السوق العربية. ولكن تُكلهم الفتاة على أنه يمكن التغلب على ذلك من خلال عمل على مشروعات مشتركة

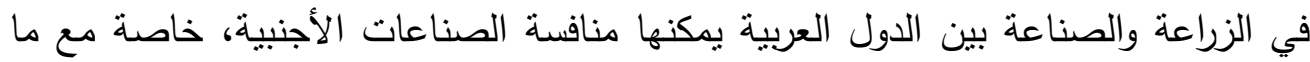

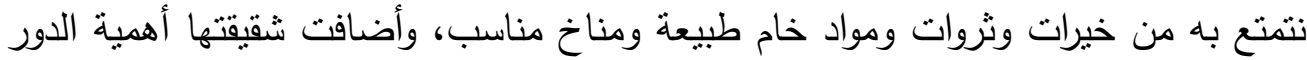

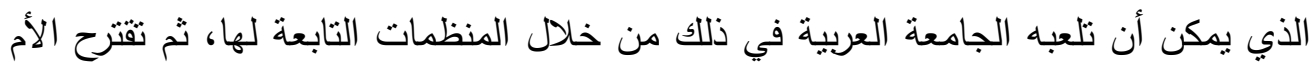

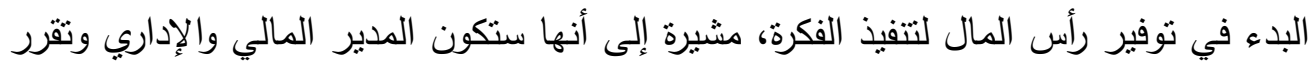

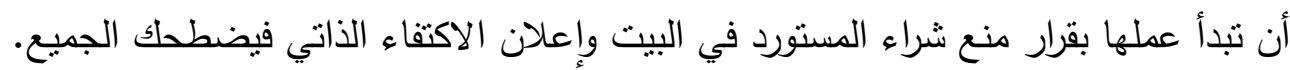

ج-مرحلة تحويل النص المسرحي لعرض داخل الفصل: بعد الانتهاء من مرحلة الإعداد المسرحي للوحدة المنهجية بدأت مرحلة تجسيد هذا لفصل

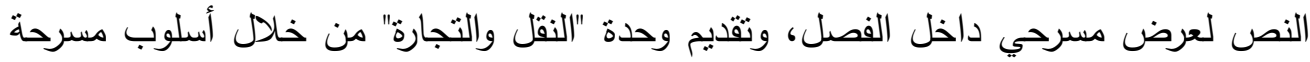

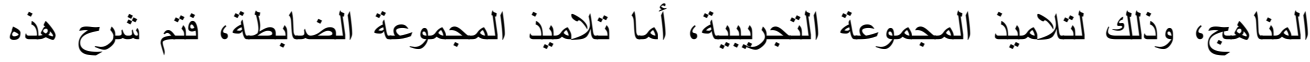

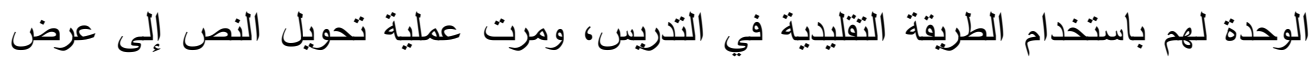

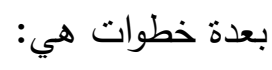

1-تم قراءة النص على تلاميذ الفصل عينة البحث وسماع آراء التلاميذ واستفساراتهم حول

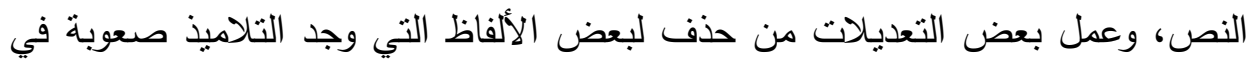

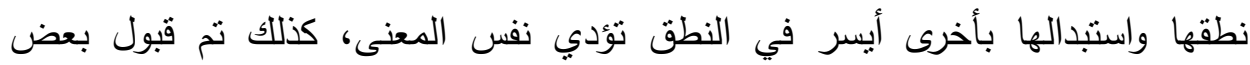

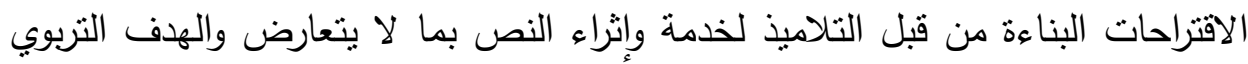

$$
\text { والتعليمي للنص. }
$$

r- عمل بروفة منضدة وسماع جميع التلاميذ عينة البحث في مختلف الأدوار والثخصيات الدرامية.

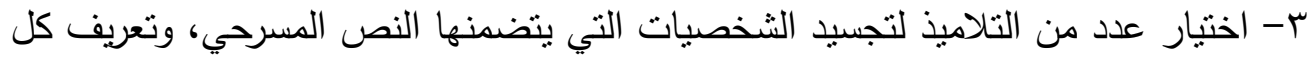

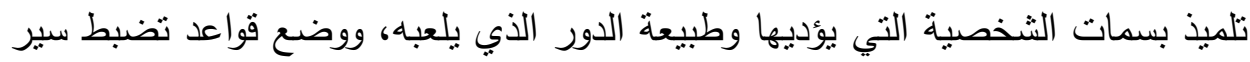

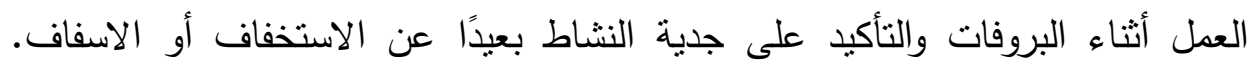
وضرورة حفظ كل تلميذ لدوره وإتقانه. 
ـ - استغلال أوقات الفراغ لتلاميذ المجموعة التجريبية لتدريبهم على العرض المسرحي من خلال بروفات الحركة والأداء كما لم يغفل الباحث أن يتم التدريب في مكان مماتل لمكان

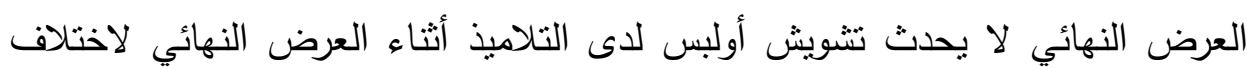
مساحة التمثيل أو غير ذلك مما يمكن أن يقع من مفاجآت غير مرغوبة.

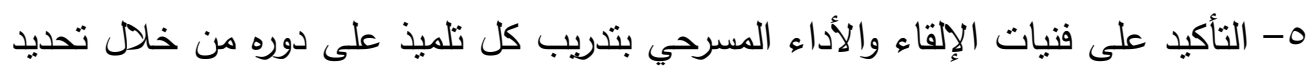
مدى الصوت وطبقته ولونه، وأيضًا توجيه انفعالاته واستخلال طاقاته الصوتية بما بلائي طبيعة الثخصية التي يؤديها. צ- تم تحديد رؤية إخراجية للنص المسرحي داخل الفصل تعتمد على الأسلوب الملحمي،

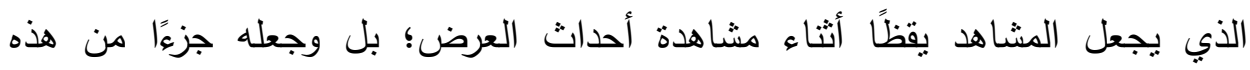

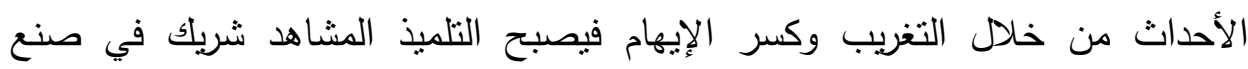
الأحداث، والاستفادة من شخصبة الراوي في التقديم للأحداث والانتقال بها والتعقيب عليها. V- نم تعريف التلاميذ بأماكن الدخول والخروج، وتدريبهم على الحركة وعمل بروفات مكثقة حتى ينقن كل تلميذ للشخصية التي يؤديها.

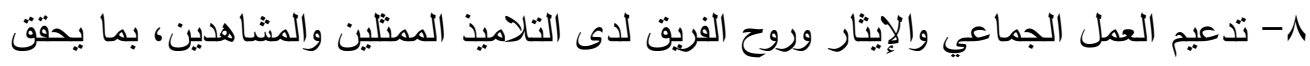

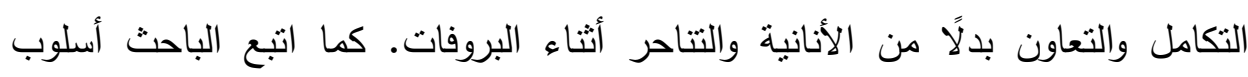

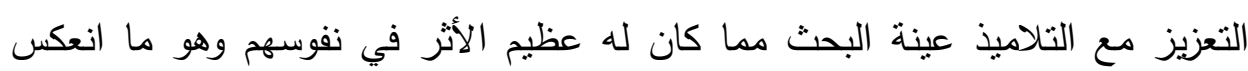
إيجابًا على أدائهم وتعاونهم وحرصهم على نجاح العمل. 9- البدء في تتفيذ مكملات العرض المسرحي أثناء سير البروفات اعتمادًا على الخامات وحردات البديلة وتدوير القطع. • ا-جاء الديكور معبرًا عن عناصر الزمان والمكان الذي تدور فيه الأحداث، وحرص

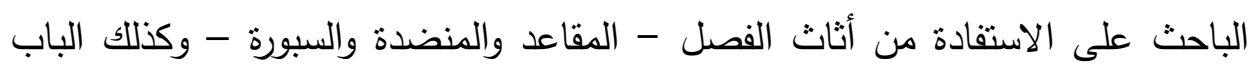
والنوافذ، كما راعى أماكن دخول وخروج المثنلين أثناء تصميمه للايكور معندةًا أثناء

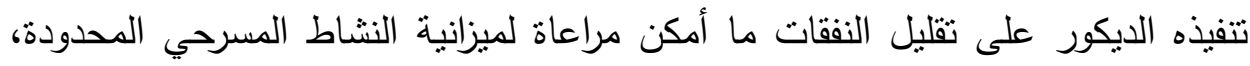

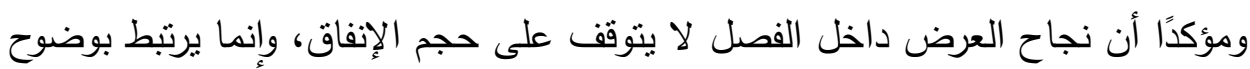
الروية والهاف لدى القائمين عليه. ذلك أن عروض مسرحة المناهج وسيلة لا غاية. 1) وبالتالي اعتمد العرض على الإضاءة الطبيعة، ولم يتم استخدام أي من الإضاءة 
المسرحية (العامة أو الخاصة)، كما أن أسلوب الإخراج كان يعتمد على الوضوح في

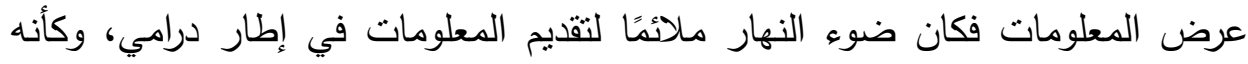
يكثف النقاب عنها لتجليتها وتوضيحها، ولم يسع الباحث في تجربته إلى الإبهار، فلم يلجأ إلى تأجير أجهزة للإضاءة المسرحية، وذلك حتى تأتي نتائجه ممثلة للواقع وقابلة للتنفيذ في حدود تلاك الإمكانيات المحدودة للأنشطة المسرحية بالمدارس. rا-نظرًا لأن مسرحية "همزة وصل" تدور أحداثها في صالة منزل، لذا جاءت أزياء الثخصيات من ملابس الحياة اليومية فالأب يرتدي بيجامة بيتي، وكذلك كانت ملابس

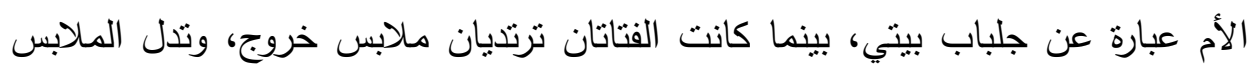
على المستوى الاجتماعي الاقتصادي للثخصيات التي ترنديها، وهي ملابس ملائمة مابنة

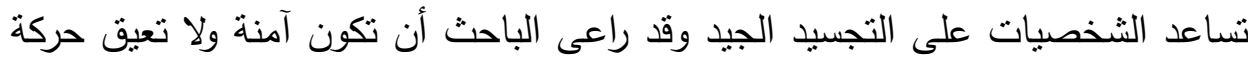

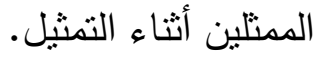
rا - استخدم الباحث بعض الملحقات المسرحية التي تسهم في إظهار وإبراز المعني مما يساعد على جذب انتباه المشاهدين للعرض المسرحي، ومن هذه الملحقات التي استخدمها

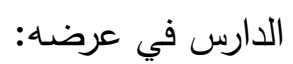

أ- ملحقات يدوية: يستخدمها الممثل أثناء قيامه بالتمثنل، وهي بسيطة حيث تتمثل في كثكول تحمله إحدى الفتبات، وجهاز كمبيوتز "لاب توب"، وشهادة تخرج من الجامعة.

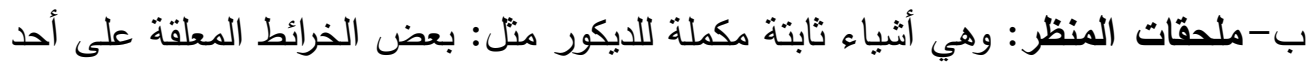
جدران الفصل (السبورة)، والتى توضح منتجات الدول العربية، وكذلك الطرق وممرات

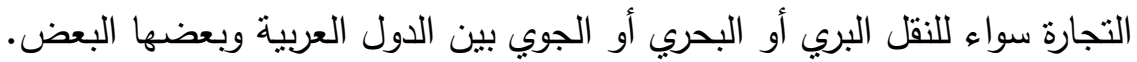
؛ 1-تم الاعتماد على بعض الإكسسوارات التي تستخدم للزينة وتوضح حالة صاحبه، ولذا

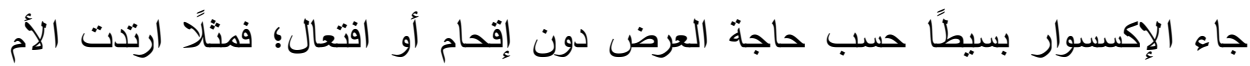
قرطًا في أذنبها، وخاتمًا ودبلة في يدها اليسرى، وهذا يوضح أنها سيدة سيدة كبيرة ومتزوجة. ه 1-اعتمد الباحث في عرضه على بعض الموثرات الصوتية التي تؤكد عوامل الزمان

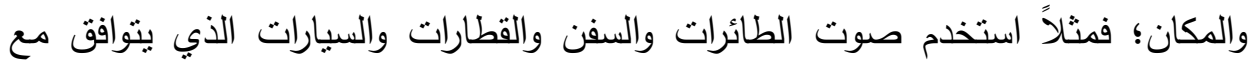
الحوار عن وسائل النقل مما يجعل التلميذ يعبش المعلومة ويتلقاها من خلال الخبرة الحياتية.

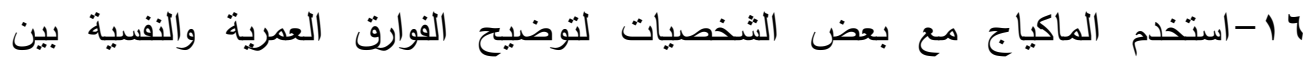
النخصيات، وخاصة أن التلاميذ الذين يلعبون الأدوار في مرحلة عمرية واحدة تقريبًا؛ 


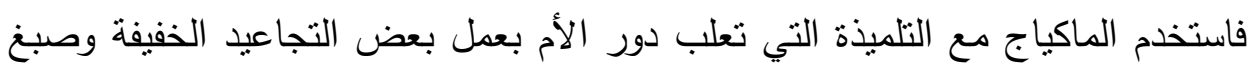

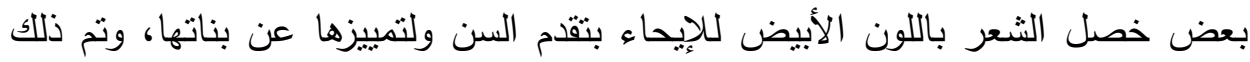

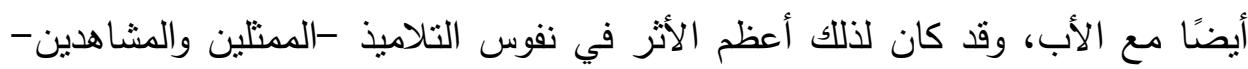

$$
\text { وخلق نوع من الإثارة والمتعة. }
$$

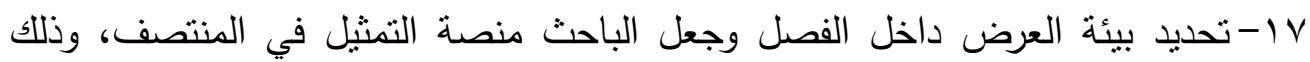
حتى يغير من شكل الفصل الذي ارتبط في ذهن التناميذ بالتلقين والملل، وجعله مكانًا

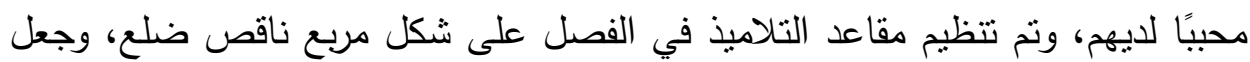

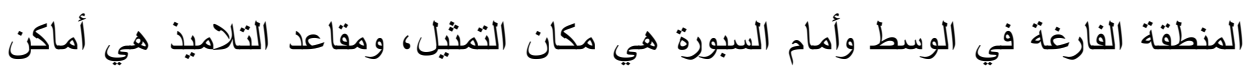

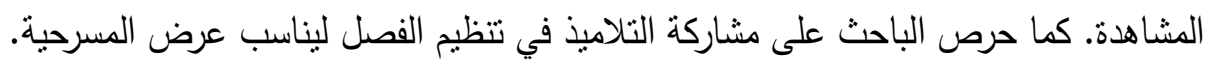

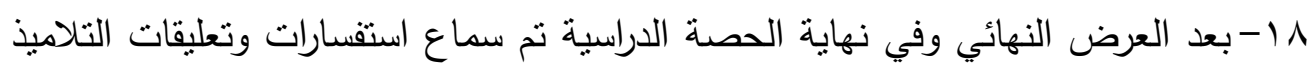
على العرض والاهتمام برجع الصدى لما شاهدوه والتأكيد على القيم الإيجابية والتغلب على السلوكيات السلبية بهدف ترسيخ الفضيلة بين التناميذ. ومما سبق يتضح أن الباحث في تتفيذه للعرض المسرحي اعتمد على البساطة، وحاول

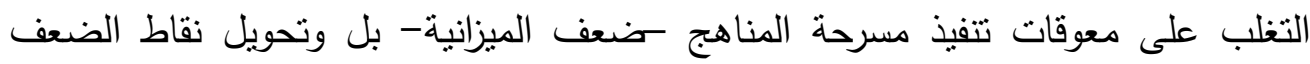

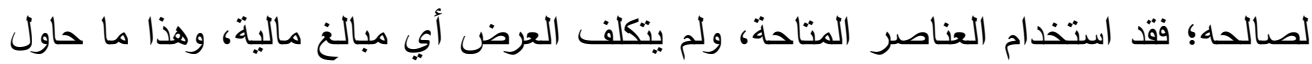

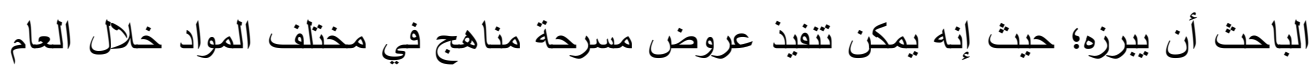

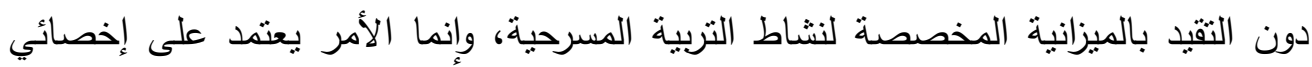

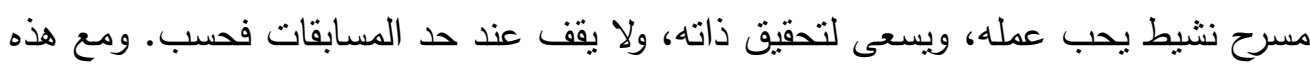

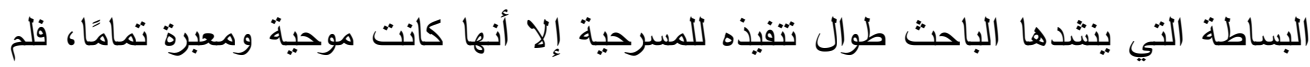

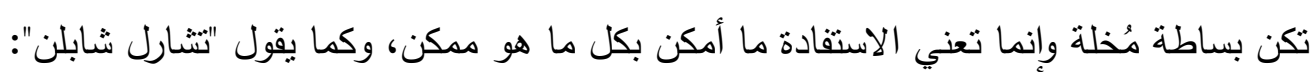

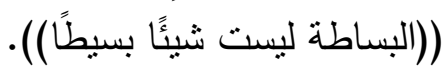

\section{رابعًا: اجراء المعالجة الإحصائية:}

اعتمد الباحث في إجراء المعالجة الإحصائية على برنامج spss لمعرفة الفروق بين درجات المجموعتين التجريبية والضابطة على الاختبار التحصيلي القبلي والبعدي. نتائج البحث وتفسيرها: بحتوي هذا الجزء على خلاصة ما توصل إلبه البحث الراهن من نتائج فاعلية مسرحة

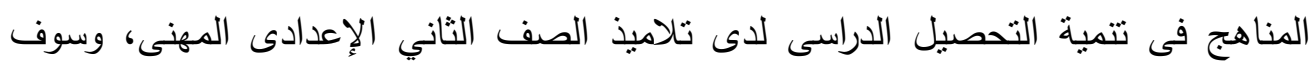

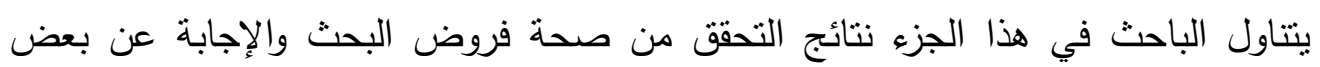


تساؤلاته البحثية، ثم يقدم ملخصًا عن هذه النتائج وتفسبرًا لها، والتي في ضوئها يمكن طرح عدد من المقترحات والتوصيات.

وفي ضوء أهداف البحث وفروضه سوف يتت عرض نتائج التحقق من صحة الفروض فيما يلي:

ثالثا : نتائج التحقق من صحة الفروض : يحتوي هذا الجزء على خلاصة ما توصلت إليه الدراسة الراهنة من نتائج فاعلية مسرحة

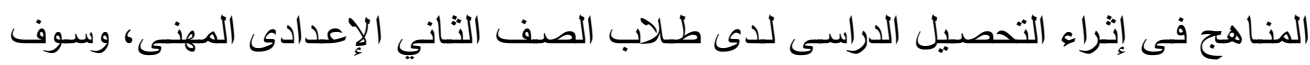

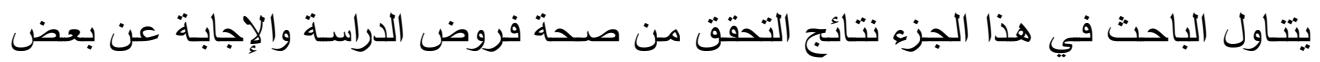

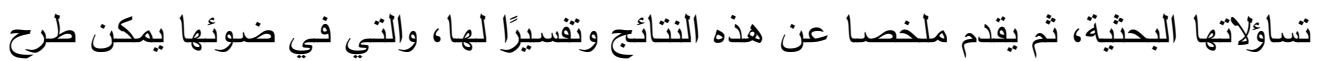
عدد من المقترحات والتوصيات. وفي ضوء أهداف الدراسة وفروضها سوف يتت عرض نتائج التحقق من صحة الفروض

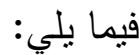

الفـرض الأول : لا توجــ فروق ذات دلالـة إحصـائبة بـين متوسـطات درجـات المجموعـة

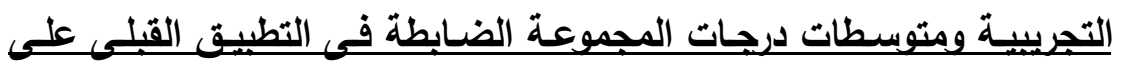

\section{الاختبار التحصبلح.}

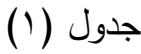

نتائج اختبار (ت) لدلالة الفروق بين متوسطات درجات المجموعة التجريبية والضابطة فى التطبيق القبلى على الاختبار التحصيلى سلى

\begin{tabular}{|c|c|c|c|c|c|c|c|}
\hline لدلالة & المرجة & الحرية & قيمة ت & المعياري & المتوسط & العدد & موعات \\
\hline غير & \multirow{2}{*}{. $\leqslant \wedge \uparrow$} & \multirow[t]{2}{*}{, } & \multirow{2}{*}{$\cdot v \cdot 1$} & r.ros & $9.1 \%$ & $r$. & الضابطة قبلى \\
\hline دالة & & & & r.OrA & $9.0 \mathrm{~V}$ & $r$. & التجريبية قبلى \\
\hline
\end{tabular}

تشبير نتائج اختبار "ت" فى الجدول السابق إلى عدم وجود فروق ذات دلالمة إحصائية بين متوسطات درجـات طـلاب المجموعـة التجريييـة ومتوسطات درجـات طـلاب المجموعـة الضابطة فى التطبيق القبلى للاختبار التحصيلى لدى طلاب الصف الثاني الإعدادى المهنى،

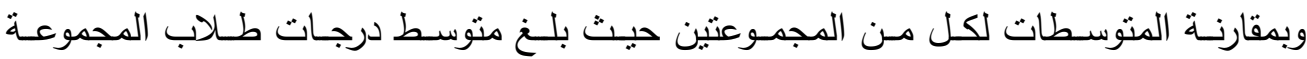

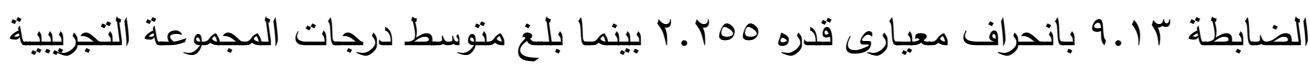
9.OV

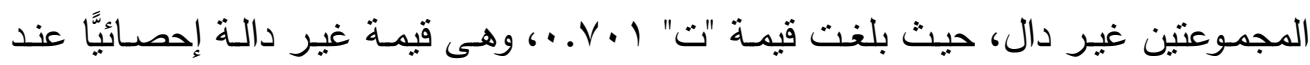


مستوى معنوية ه ... ، وبالتالى فقد يثبت صحة هذا الفرض . والذى ينص على أنه لا توجد

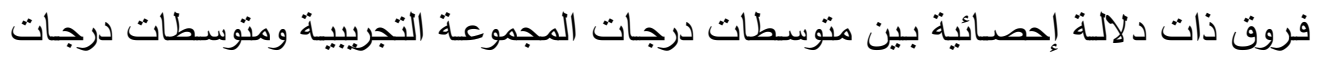

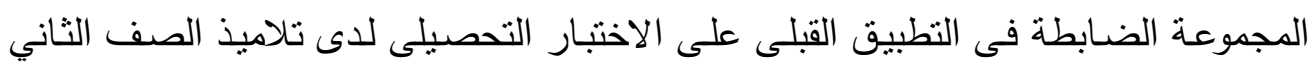
الإعدادى المهنى، أى أن هناك تجانسًا بين المجموعتين التجريبية والضابطة.

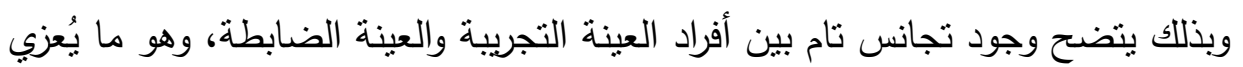
أي نتائج فرقية بين المجموعتين لصالح المجموعة التجريبية.

الفـرض الثانى : لا توجــ فروق ذات دلالـة إحصـائية بـين متوسبطات درجـات المجموعـة

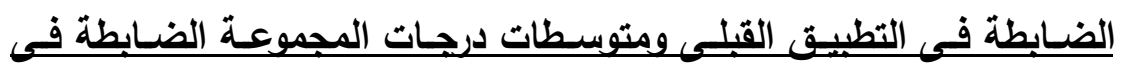

\section{التطبيت البعدى على الاختبار التحصبلح.}

جدول (r)

نتائج اختبار (ت) لدلالة الفروق بين متوسطات درجات المجموعة الضابطة على كل من التطبيق

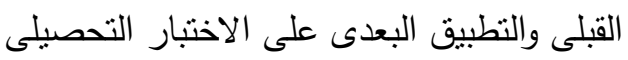

\begin{tabular}{|c|c|c|c|c|c|c|c|}
\hline الدلالة & المعنوية & الدرجة & قيمة ت & الانحراف & المتوسط & العدد & المجموعات \\
\hline \multirow{2}{*}{ غالة } & \multirow{2}{*}{. .171} & \multirow{2}{*}{ rq } & \multirow{2}{*}{$1 . \leqslant r q$} & r.ros & $9.1 \%$ & $r$. & الضابطة قبلى \\
\hline & & & & $1.9 \times 0$ & 9.ะ. & $r$. & الضابطة بعدى \\
\hline
\end{tabular}

تشبير نتائج اختبار "ت" فى الجدول السابق إلى عدم وجود فروق ذات دلالة إحصائية

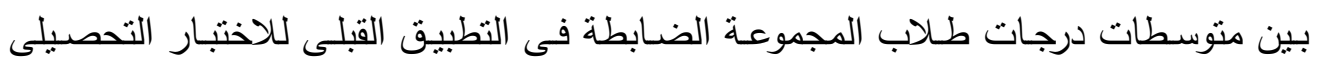

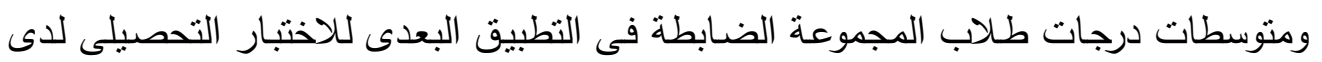

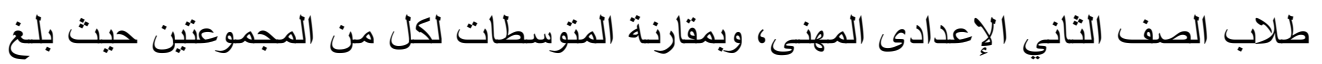

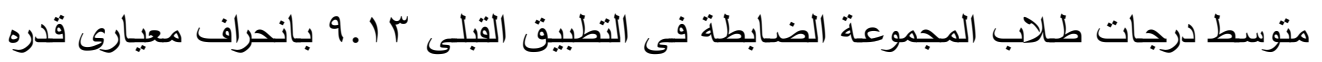

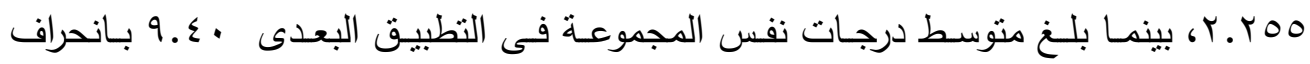

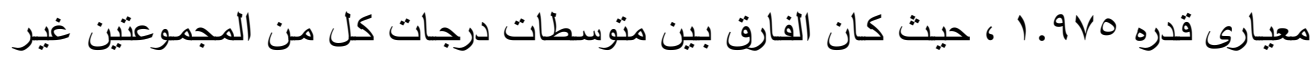

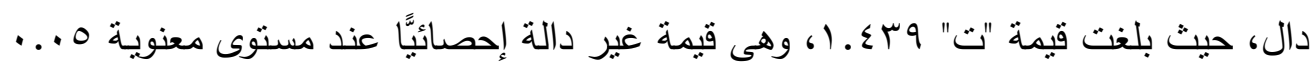

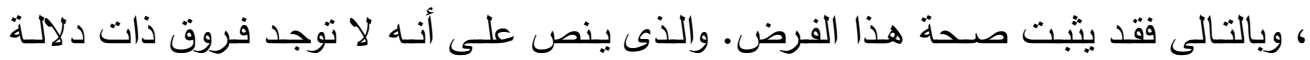
إحصائية بين متوسطات درجات المجموعة الضابطة فى التطبيق القبلى ومنوسطات درجات

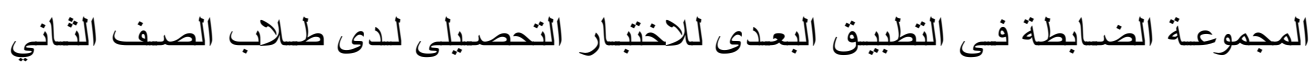
الإعدادى المهنى. 


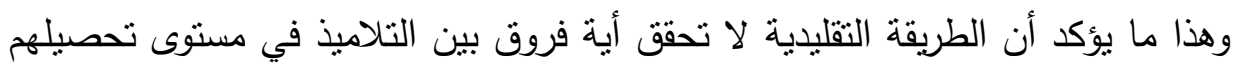

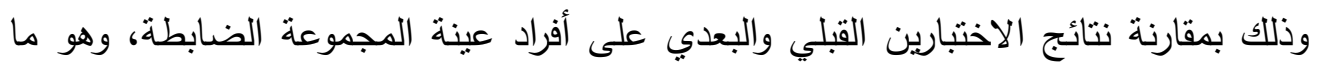
يدلل أيضًا على أنه في حالة وجود فروق في درجات الاختبار التحصلي البعدي عنه في

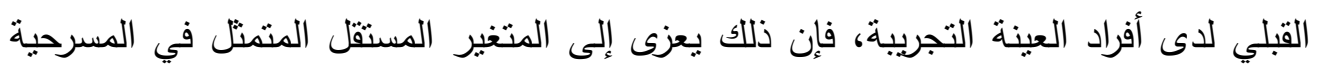

المنهجية.

الفرض الثالث : توجد فروق ذات دلالة إحصائبة بين متوسطات درجات المجموعة الضـابطة

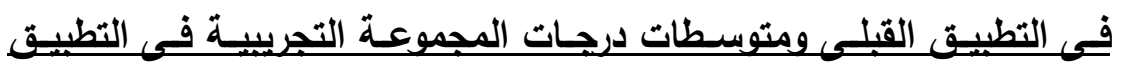

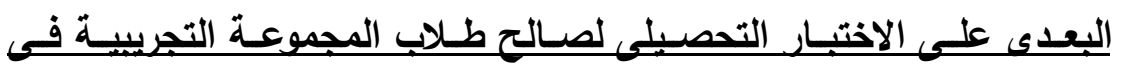

\section{التطييق البعدى.}

\section{جدول (r)}

نتائج اختبار (ت) لدلالة الفروق بين منوسطات درجات المجموعة الضابطة فى التطبيق

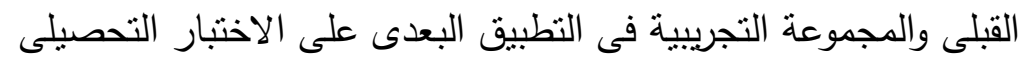

\begin{tabular}{|c|c|c|c|c|c|c|c|}
\hline الدلالة & المعنوية & الحرية & قيمة ت & الانحراف & المتوسط & العدد & المجموعات \\
\hline \multirow{2}{*}{ دالة" } & \multirow{2}{*}{$\ldots \ldots$} & \multirow{2}{*}{$\Delta \wedge$} & \multirow{2}{*}{ rı.Av } & r.ros & 9.14 & $r v$ & الضابطة قبلى \\
\hline & & & & YV.rq & rV.rT & $r v$ & التجريبية بعدى \\
\hline
\end{tabular}

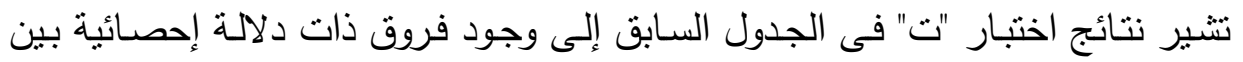

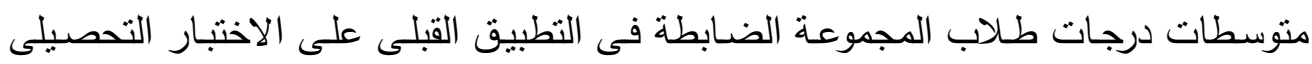

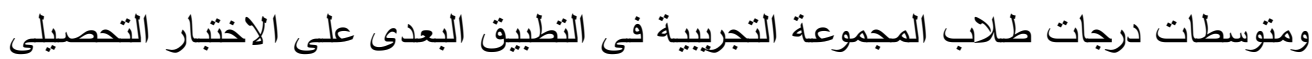

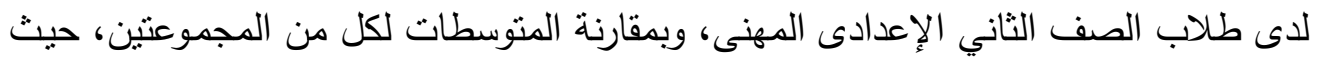

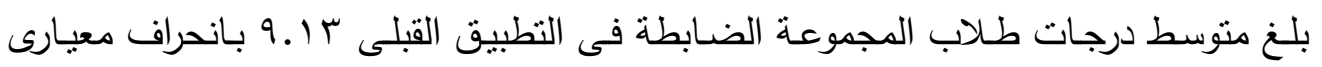

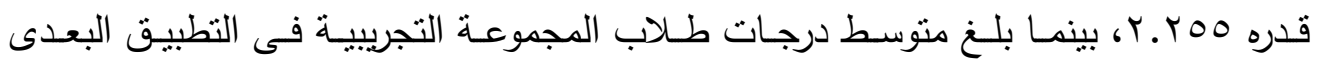

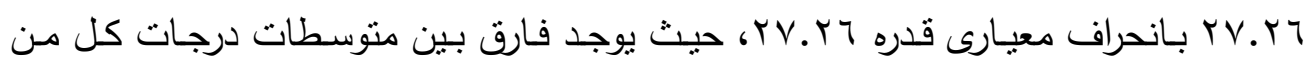

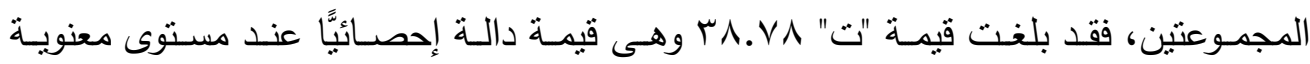

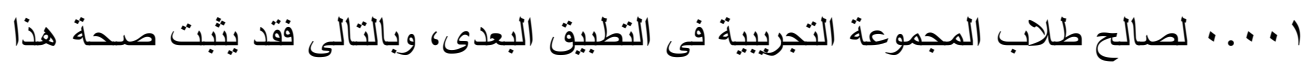

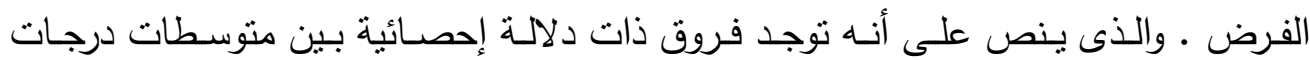

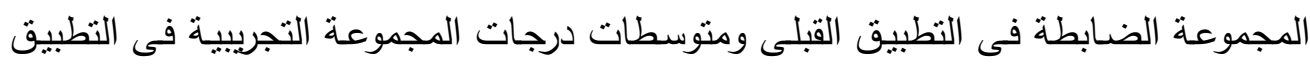


البعدى على الاختبار التحصيلى لدى تلاميذ الصف الثاني الإعدادى المهنى لصالح طلاب المجموعة التجريبية فى التطبيق البعدى. وتؤكد نتائج هذا الفرض على أن الفروق في الدرجات بين الاختبار التحصيلى البعدي

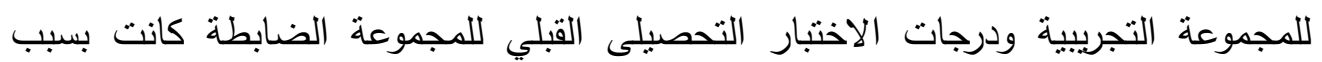

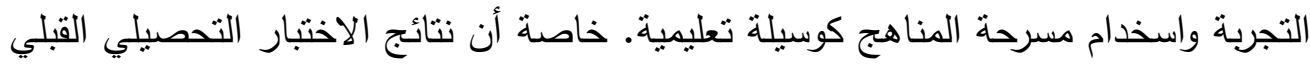
والبعدي للمجموعة الضابطة التي درست الوحدة عينة البحث بالطريقة التقليدية تؤكد على عدم التئه

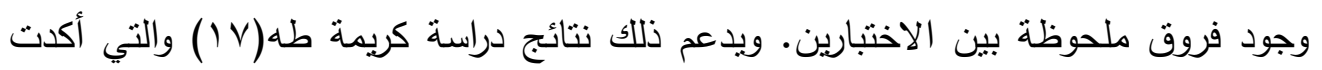

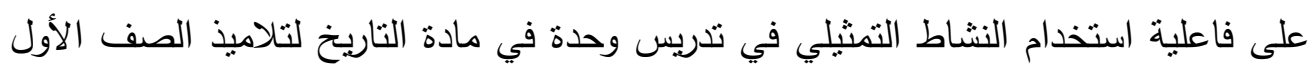
الإعدادي في تتمية مهارة اتخاذ القرار لدى التلاميذ، وكذلك أثره على تحصيل التلاميذ للمعرفة مادة التاريخية. وتوصلت إلى وجود فروق دالة إحصائًًا بين منوسط درجات تنلاميذ المجموعة

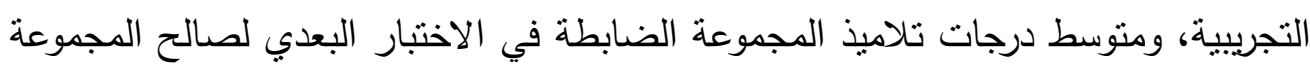
التجريبية. وكذلك وجود علاقة بين منوسطات درجات تحصيل تلاميذ المجموعة التجريبية ومستوى اكتسابهم لمهارة اتخاذ القرار في التطبيق البعدي.

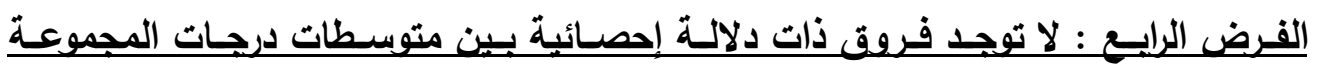

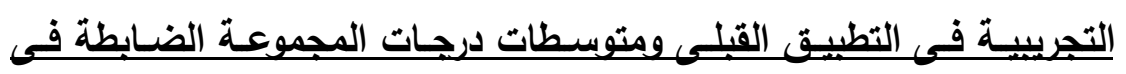
التطبيق البعدى على الاختبار التحصبلى.

$$
\text { جدول (乏) }
$$

نتائج اختبار (ت) لدلالة الفروق بين منوسطات درجات المجموعة التجريبية فى التطبيق

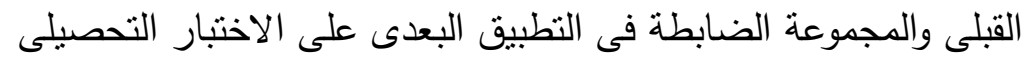

\begin{tabular}{|c|c|c|c|c|c|c|c|}
\hline الدلالة & المرجنة & الحرجة & قيمة ت & الانحراف & المتوسط & العدد & المجموعات \\
\hline غير & \multirow{2}{*}{.$V \vee V$} & \multirow{2}{*}{$0 \wedge$} & \multirow{2}{*}{.rAo } & r.OYA & 9.07 & $r$. & تجريبية قبلى \\
\hline دالة & & & & $1.9 \vee 0$ & 9.६. & r. & ضابطة بعدى \\
\hline
\end{tabular}

تشير نتائج اختبار "ت" فى الجدول السابق إلى عدم وجود فروق ذات دلالة إحصائية

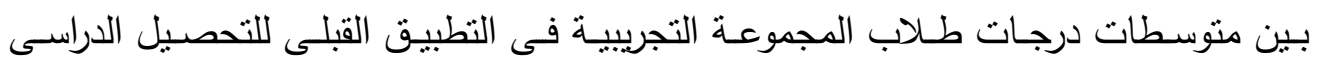

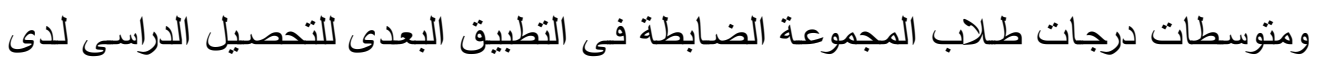

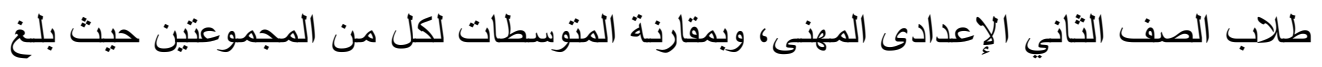


منوسط درجات طلاب المجموعة التجريبية فى التطبيق القبلى 9.07 بانحراف معيارى قدره

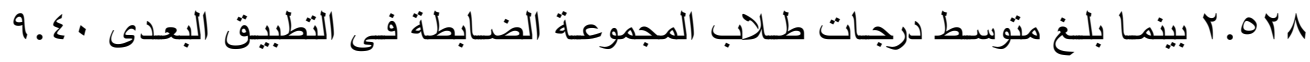
بانحراف معيارى قدره 1 .9V0 ، حيث كان الفارق بين متوسطات درجات كل من المجموعنين

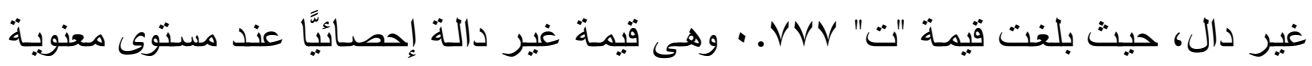

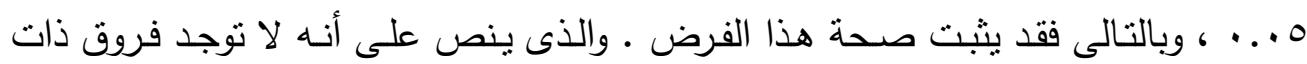

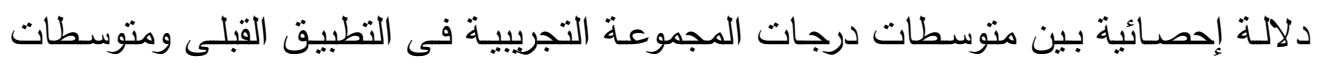

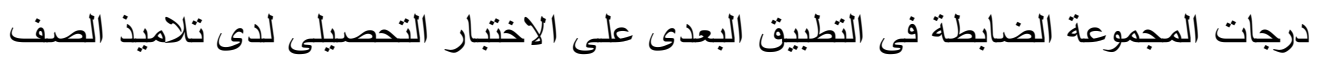

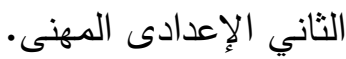

ونتيجة هذا الفرض أيضًا تدلل على أن الفروق في الدرجات لصالح المجموعة التجريبية

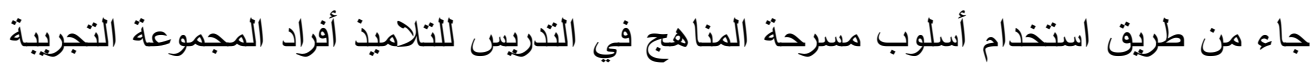
وهو ما يدعم أهمية البعد عن الطريقة القليدية في التدريس والاهتمام بالتعليم من خلاهل الدراما خاصة مع هذه الفئة من التلاميذ الذين يعزفون في الغالب عن التعليم التقليدي.

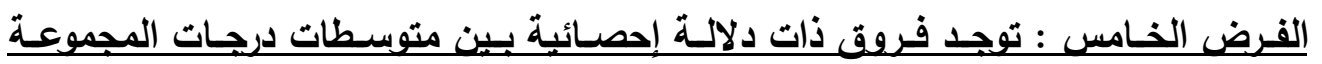

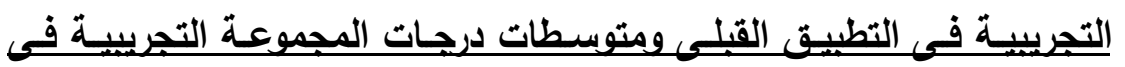
التطييق البعدى على الاختبار التحصيلى لصـالح طلاب المجموعة التجريبية

$$
\text { فحى التطبيق البعدى. }
$$

جدول (0)

نتائج اختبار (ت) لدلالة الفروق بين متوسطات درجات المجموعة التجريبية على كل من التطبيق القبلى والتطبيق البعدى على الاختبار التحصيلى لئى

\begin{tabular}{|c|c|c|c|c|c|c|c|}
\hline الدالة & المعنوية & الحرية & قيمة ت & الانحراف & المتوسد & العدد & المجموعات \\
\hline \multirow{2}{*}{ دالة * } & \multirow{2}{*}{$\cdots \cdots$} & \multirow{2}{*}{ rq } & \multirow{2}{*}{$\Gamma \neg . \Gamma \leq \Lambda$} & r.OYA & 9.07 & $r$. & تجريبية قبلى \\
\hline & & & & $1 . r \cdot 1$ & YV.YT & $r$. & تجريبية بعدى \\
\hline
\end{tabular}

تشير نتائج اختبار "ت" فى الجدول السابق إلى وجود فروق ذات دلالة إحصائية بين

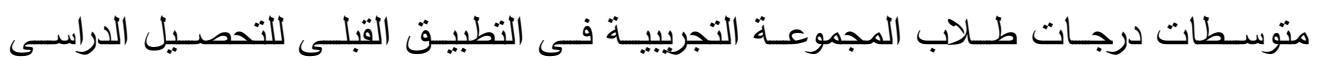

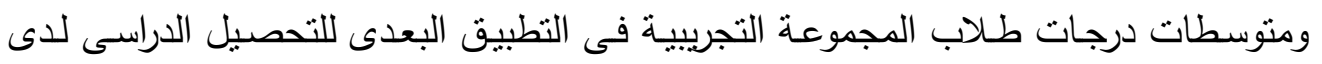


طلاب الصف الثاني الإعدادى المهنى، وبمقارنة المتوسطات لكل من المجموعتين حيث بلغ متوسط درجات طلاب المجموعة التجريبية فى التطبيق القبلى 9.07 بانحراف معيارى قدره

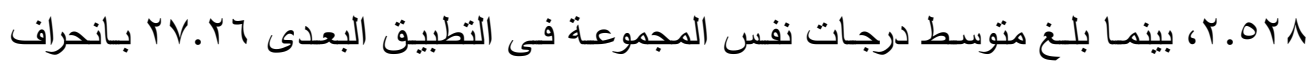

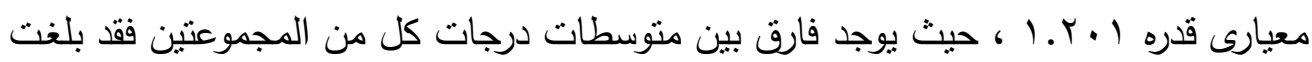

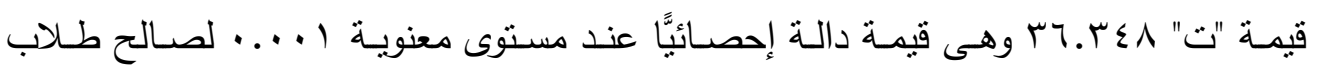

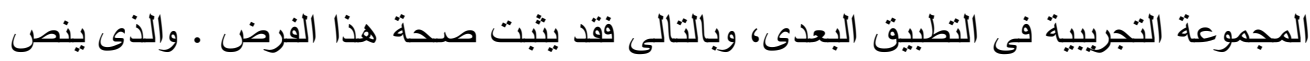

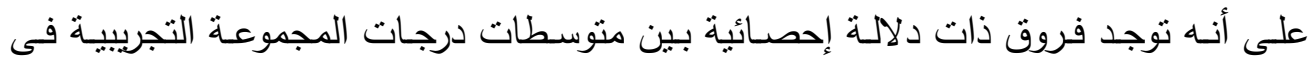
التطبيق القبلى ومتوسطات درجات المجموعـة التجريبية فى التطبيق البعدى على الاختبار

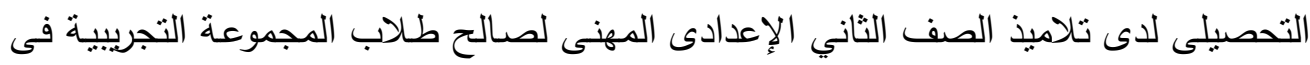

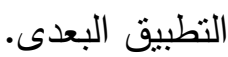

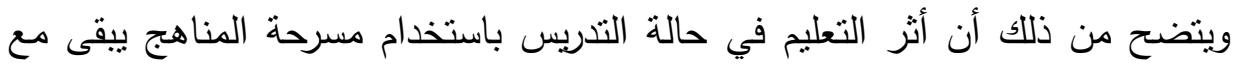
التلاميذ، بخلاف الطريقة التقليدية التي تؤكد نتائج الاختبار القبلي والبعدي للمجموعة بلته

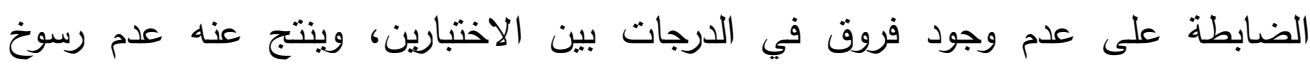
المعلومات في ذهن هؤلاء التلاميذ، وهذا يؤكد فاعلية التجربة من خلال مسرحة المناهج.

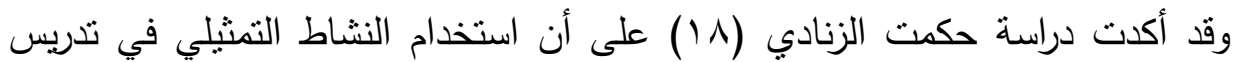

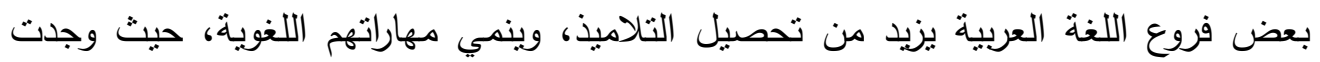
فروق دالة إحصائيًا لصالح المجموعة التجريبية.

الفـرض السـادس : توجد فـروق ذات دلالـة إحصـائبة بـين متوسـات درجـات المجموعـة

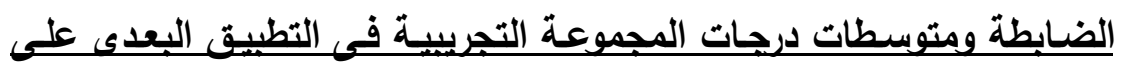

الاختبار التحصيلى لصالح طلاب المجموعة التجريبية فى التطيق البعدى.

جدول (7)

نتائج اختبار (ت) لدلالة الفروق بين متوسطات درجات المجموعة الضابطة والتجريبية فى هي

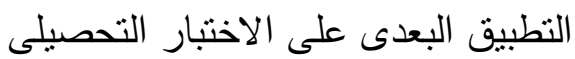

\begin{tabular}{|c|c|c|c|c|c|c|c|}
\hline للة الدا & المعنوية & الحرية & قيمة ت & الانحراف & المتوسط & العدد & وعات \\
\hline دالة & \multirow{2}{*}{$\ldots \ldots$} & \multirow{2}{*}{$0 \wedge$} & \multirow[t]{2}{*}{$\varepsilon r . r r$} & $1.9 \times 0$ & 9.\&. & $r$. & ضابطة بعدى \\
\hline$* * *$ & & & & $1 . r \cdot 1$ & PV.rT & $r$. & تجريبية بعدى \\
\hline
\end{tabular}


تتبير نتائج اختبار "ت" فى الجدول السابق إلى وجود فروق ذات دلالة إحصائية بين

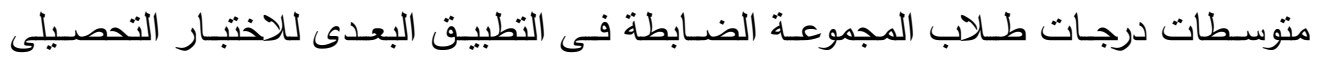
ومنوسطات درجات طلاب المجموعة التجريبية فى التطبيق البعدى للاختبار التحصيلى لدى

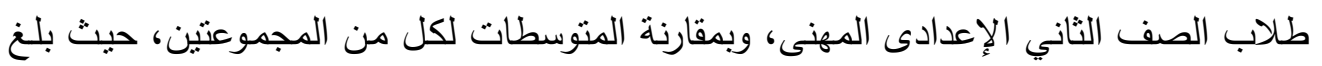
متوسط درجات طلاب المجموعة الضابطة فى النطبيق البعدى • ؛ 9 بانحراف معيارى قدره

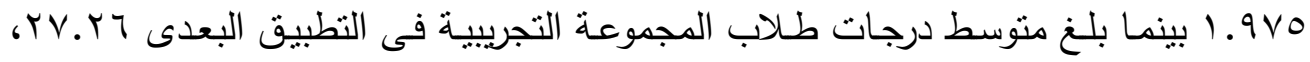

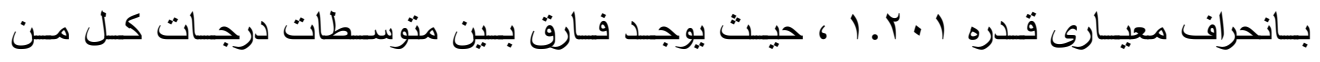

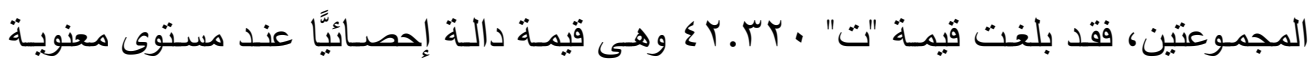

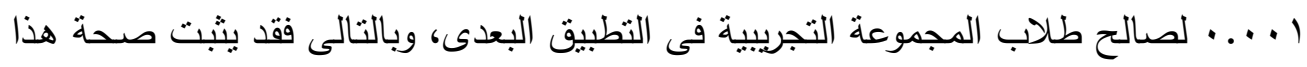

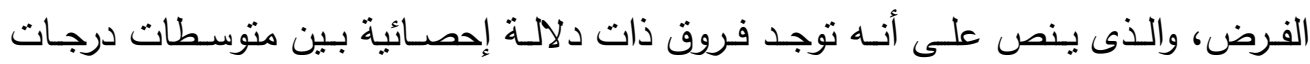

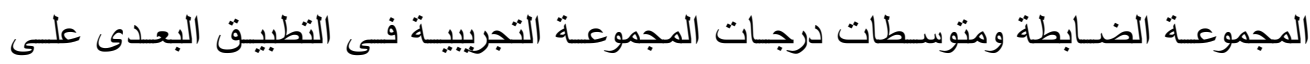
الاختبار التحصيلى لدى تلاميذ الصف الثاني الإعدادى المهنى لصـالح طـلاب المجموعـة التجريبية فى التطبيق البعدى.

وعلى هذا فقد ثبت بالتجربة فاعلية توظيف مسرحة المناهج في تدريس المقررات الدراسية لهذه الفئة من تلاميذ المدارس الإعدادية المهنية، وأن هذه الطريقة تترك أثرًا أطول لبقاء المعلومات لدى هؤلاء التلاميذ وتمكنهم من سهولة استراجاع هذه المعلومات عند الحاجة إليها، كما أن التدريس من خلال مسرحة المناهج يسهم في جذب التلاميذ للإقبال على التعليم بما تحققه من تقديم المعلومة في إطار درامي محبب لاى التلاميذ، ويصبح التلميذ شريكًا في صنع الحدث وتقديم المعلومة وتلقيها بما يحقق له فرصة للتعلم من خلال الخبرة بعيدًا عن التلقين وحفظ المعلومة واستظهارها. وهو ما تؤكده دراسة Piggins, Carol, Ann (9 (1) بعنوان:

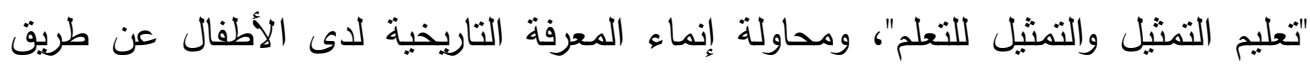

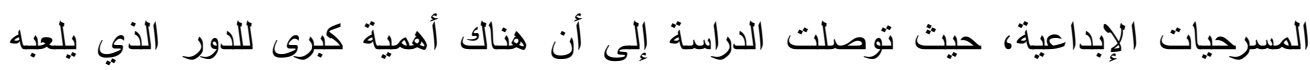
المعلم داخل الفصل عند استخدامه المسرحيات الإبداعية فيقوم بإعداد المسرحيات المقترحة الإنهات

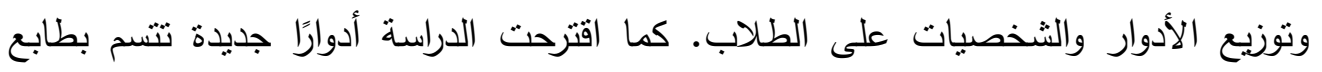
الإبداع يمكن أن يستعان بها داخل الفصل. 


\section{النتائج النهائية للبحث:}

1-أكدت نتائج البحث عدم وجود فروق دالة إحصائيًا بين منتسط درجات المجموعة التجريبية ومنوسط درجات المجموعة الضابطة فى التطبيق القبلى على الاختبار التحصبلى.

ץ-عدم وجود فروق دالة إحصائًّا بين متوسط درجات المجموعة الضابطة فى التطبيق

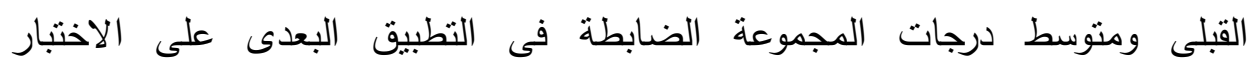
التحصيلى. ז-وجود فروق دالة إحصائيًا بين متوسط درجات المجموعة الضابطة فى التطبيق البعدي ومتوسط درجات المجموعة التجريبية فى التطبيق البعدى على الاختبار التحصيلى لصالح تلاميذ المجموعة التجريبية فى التطبيق البعدى. ع-عدم وجود فروق دالة إحصائًًا بين منوسطات درجات المجموعة التجريبية فى التطبيق القبلى ومتوسطات درجات المجموعة الضابطة فى النطبيق البعدى على الاختبار التحصيلى. ه-وجود فروق دالة إحصائًًا بين متوسط درجات المجموعة التجريبية فى التطبيق القبلى ومتوسط درجات المجموعة التجريبية فى التطبيق البعدى على الاختبار التحصيلى لصالح تلاميذ المجموعة التجريبية فى التطبيق البعدى. 7-وجود فروق دالة إحصائًّا بين متوسط درجات المجموعة الضابطة ومنوسط درجات المجموعة التجريبية فى التطبيق البعدى على الاختبار التحصيلى لصالح تلاميذ المجموعة التجريبية فى التطبيق البعدى.

\section{ويناء على النتائج السابقة يتضح ما يلي:}

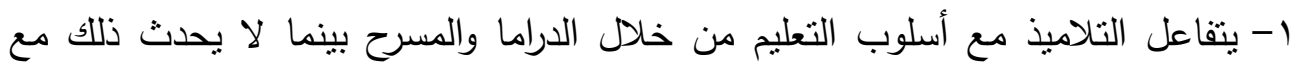

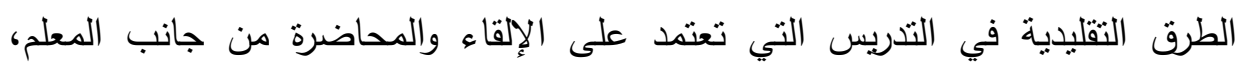
والحفظ والإستظهارمن جانب التلاميذ. ץ- تلعب مكملات العرض المسرحي دورًا مهمًّا في خلق الإثارة والتشويق لدى جمهور التلقي

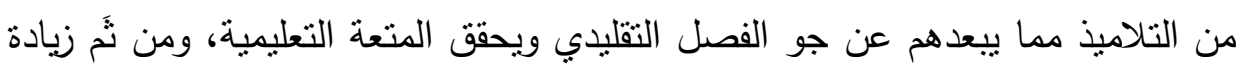
التحصيل الدراسي لديهم. 
r-بحقق مجال مسرحة المناهج اتجاهًا ايجابيًّا لدى التلاميذ نحو الددرسة وتحقيق نواتج التعلم المستهدفة بشكل عام.

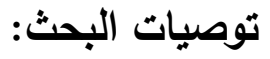

1-ضرورة اهتمام وزارة التربية والتعليم بتفعيل التعليم بالدرما والاستفادة من إمكانيات مسرحة

$$
\text { المناهج داخل مدارس التعليم الإعدادي المهني. }
$$

ץ-وضع حصص لنشاط المسرح ضمن الجدول الدراسي بمدارس التعليم الإعدادي المهني

$$
\text { بشكل ثابت ومكثف. }
$$

r-ضرورة توفير إخصائي مسرح بجميع المدارس الإعدادية المهنية مما بسهم في إثراء

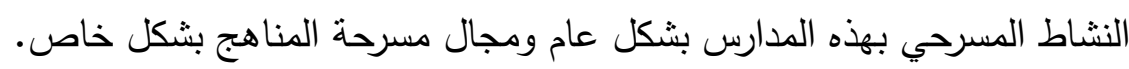

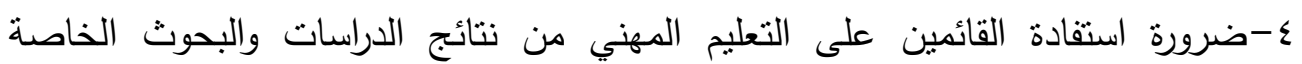
بمسرحة المناهج للارتقاء بالعملية التعليمة وجعل المدرسة عامل جذب للتناميذ لا بيئة

$$
\text { طاردة لهم. }
$$




\section{مراجع البحث:}

( ) كمال الدين حسين: مقدمة في مسرح ودراما الطفل لرياض الأطفال، ط (، مكتبة زهراء

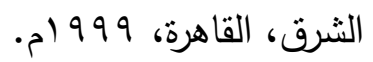

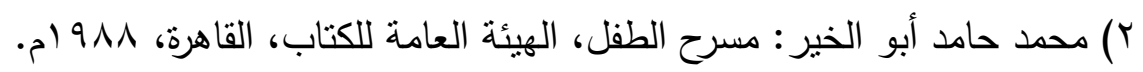
r) كمال الدين حسين: الدسرح التعليمي "الدصطلح والتطبيق"، الدار الدصرية اللبنانية،

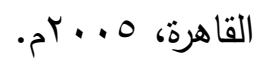

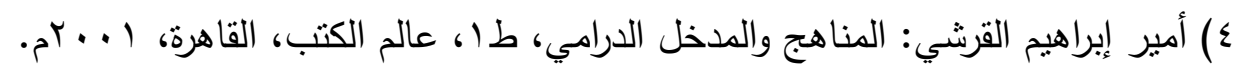

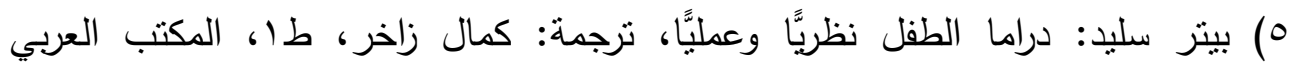

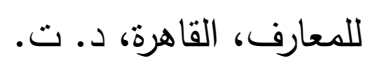

7) عبد المجيد شكري: المسرح التعليمي، طا، العربي للنشر والتوزيع، القاهرة، ع ـ . rم.

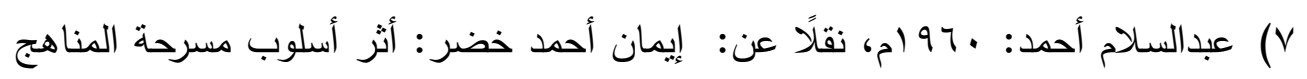

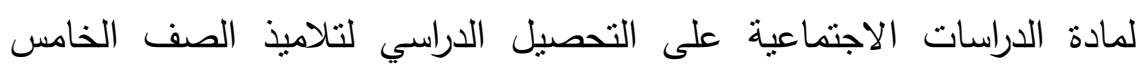

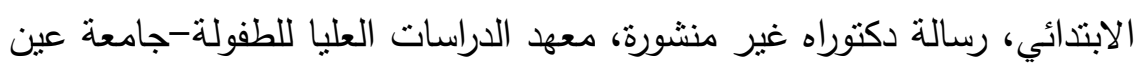

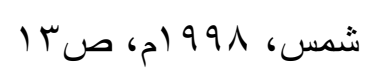

^) أبوالعزايم عبدالمنعم: دراسة للعلاقة بين الميول المهنية والتحصيل الدراسي لطلاب قسم

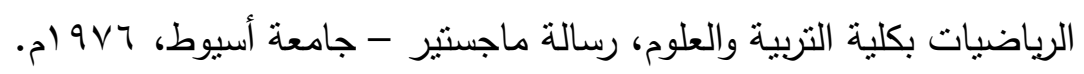

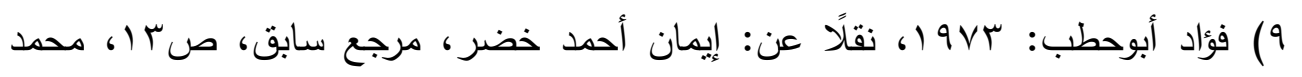
الوفائي: مناهج البحث في الدراسات الاجتماعية والإعلامية، طاه ال، مكنبة الأنجلو المصرية، القاهرة، 9 ام. لوسيل لويس برسوم: استخدام بعض الأساليب

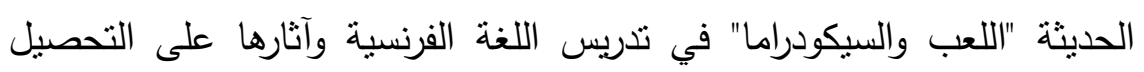

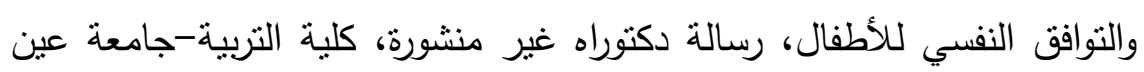

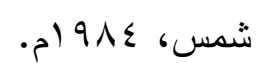

10) Piggins, Carol, Ann: " Learning to act,acting to learn ", teaching guide, learning. V. 12.N7, 1984.

11) Renee T. clift. " The Effects of Dramatic Activities on Secondary School Students Learning, Retention and Attitudes "Dissertation Abstracts International, 1985 
rا)رزق حسن عبد النبي: الطريقة الكثفية والدرامية في تدريس العلوم للمرحلة الابتدائية،

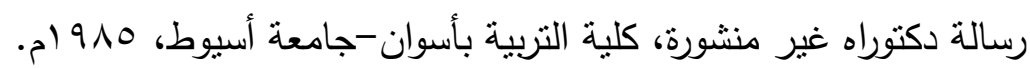

13) Stephen .H."Yaffe Drama As a Teaching Tool In Educational leader Ship", VOI .64. No.6.Maech 1989.

ع ()حكمت محمود محمد الزنادي: استخدام النشاط التمثيلي في تدريس بعض فروع اللغة

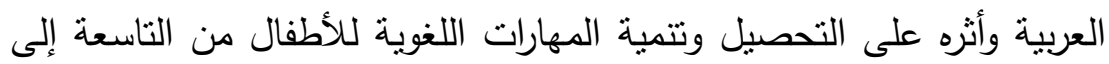
الثانية عشرة، رسالة دكتوراه غير منشورة، معهد الدراسات والبحوث التربوية-

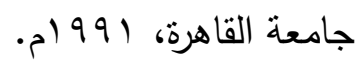
10)ملاك عازر إسكندر: مدى فعالية استخدام النشاط التشثيلي في تحقيق أهداف العلوم بالصف الرابع من التعليم الأساسي، رسالة دكتوراه غير منشورة، كلية التربية،

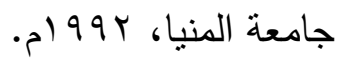
7 ()أمير إبراهيم أحمد القرشي: استخدام مسرحة المناهج في الدراسات الاجتماعية وأثنره على التحصيل ومهارات الاتصال والتوافق الاجتماعي لدى الصم، رسالة دكتوراه

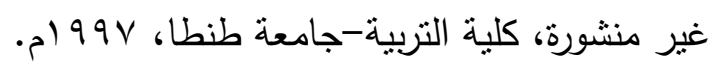
V) V V V Vحي حسانين، ماجدة عبد التواب: أثر مسرحة المناهج في فهم تلاميذ المرحلة الابتدائية

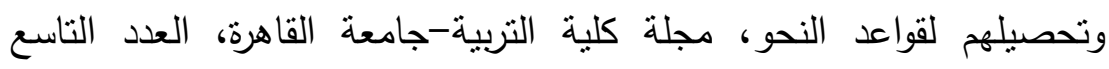
والأربعون، مايو 991 ام.

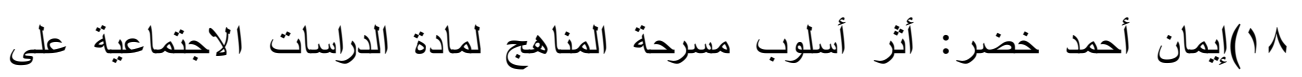

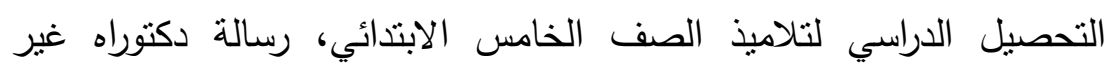

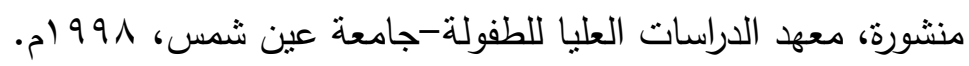

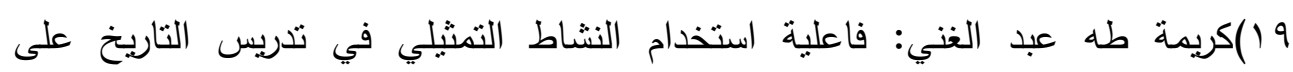

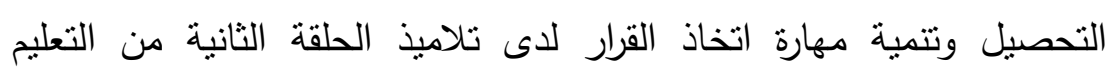

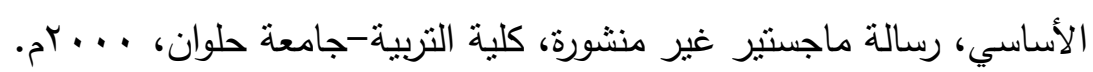

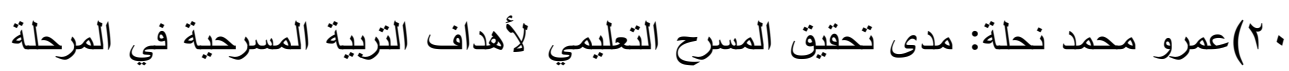

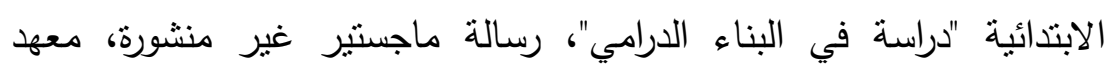

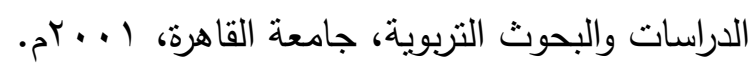


(') فتحي حسانين، ماجدة عبد التواب: أثز مسرحة المناهج في فهم تلاميذ المرحلة الابتدائية

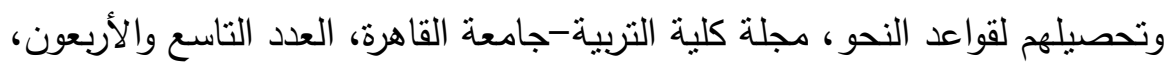

$$
\text { مايو } 991 \text { ام. }
$$

(2) Renee T. clift. "The Effects of Dramatic Activities on Secondary

School Students Learning, Retention and Attitudes

Dissertation Abstracts International, 1985

(3) رزق حسن عبد النبي: الطريقة الكثفية والدرامية في ندريس العلوم للمرحلة الابتدائية، رسالة

$$
\text { دكتوراه غير منشورة، كلية التربية بأسوان-جامعة أسيوط، } 910 \text { ام. }
$$

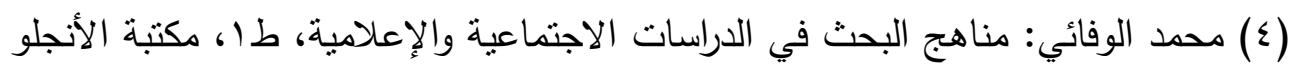

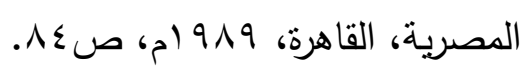

(0) كمال الدين حسين: مقدمة في مسرح ودراما الطفل لرياض الأطفال، ط ا، مكتبة زهراء الثرق،

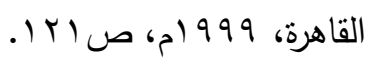

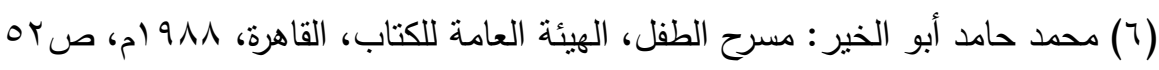

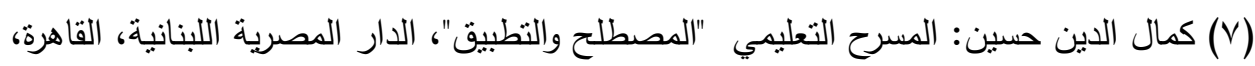

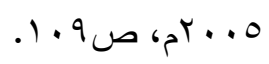

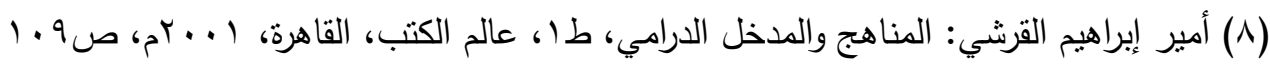

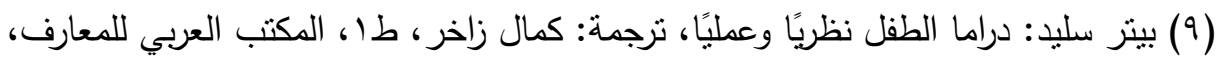

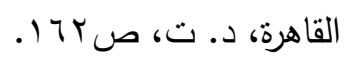

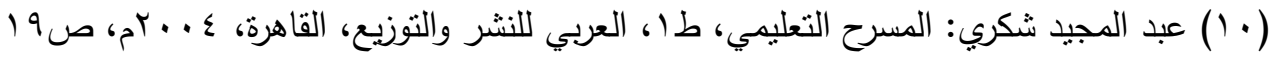

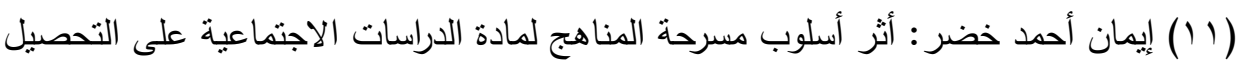

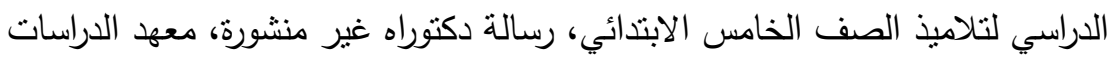

$$
\text { العليا للطفولة-جامعة عين شمس، } 991 \text { ام. }
$$

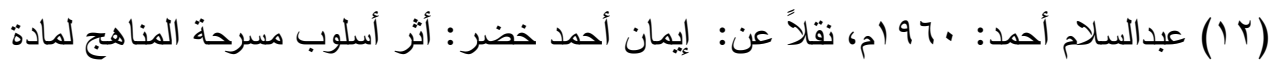

الدراسات الاجتماعية على التحصيل الدراسي لتلاميذ الصف الخامس التفان الابتدائي، رسالة

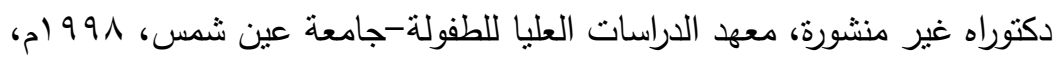

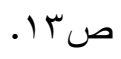

(T (1) أبوالعزايم عبدالمنعم: دراسة للعلاقة بين الميول المهنية والتحصيل الدراسي لطلاب قسم

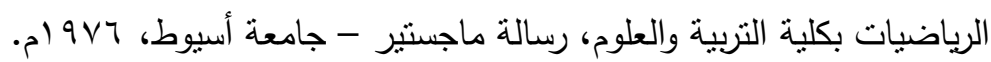




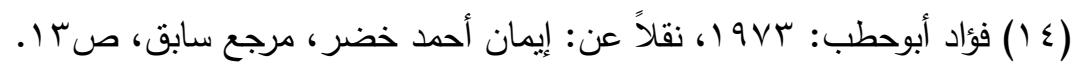

(10) كريمة طه عبد الغني: فاعلية استخدام النشاط التمثيلي في تدريس التاريخ على التحصيل وتتمية مهارة اتخاذ القرار لدى تلاميذ الحلقة الثانية من التعليم الأساسي، رسالة ماجستير غير منشورة، كلية التربية-جامعة حلوان، . . . م. م.

(7 (1)عمرو محمد نحلة: مدى تحقيق المسرح التعليمي لأهداف التربية المسرحية في المرحلة الابتدائية "دراسة في البناء الدرامي"، رسالة ماجستير غير منشورة، معهد الدراسات

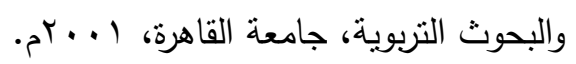

(IV) (Vريمة طه عبد الغني: فاعلية استخدام النشاط التمثيلي في تدريس التاريخ على التحصيل وتتمية مهارة اتخاذ القرار لدى تلاميذ الحلقة الثانية من التعليم الأساسي، رسالة ماجستير

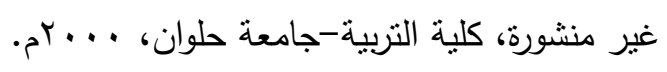

(1 (1) حكمت محمود محمد الزنادي: استخدام النشاط التمثيلي في تدريس بعض فروع اللغة العربية وأثره على التحصيل وتتمية المهارات اللغوية للأطفال من التاسعة إلى الثانية عشر ، رسالة

دكتوراه غير منشورة، معهد الدراسات والبحوث التربوية-جامعة القاهرة، إنو 99 ام.

(19) Piggins, Carol, Ann: " Learning to act,acting to learn ", teaching guide, learning. V. 12.N7, 1984. 